\title{
Regeneration in the ctenophore Mnemiopsis leidyi occurs in the absence of a blastema, requires cell division, and is temporally separable from wound healing
}

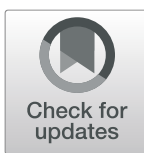

Julia Ramon-Mateu', S. Tori Ellison², Thomas E. Angelini ${ }^{2,3}$ and Mark Q. Martindale ${ }^{1 *}$ (D)

\begin{abstract}
Background: The ability to regenerate is a widely distributed but highly variable trait among metazoans. A variety of modes of regeneration has been described for different organisms; however, many questions regarding the origin and evolution of these strategies remain unanswered. Most species of ctenophore (or "comb jellies"), a clade of marine animals that branch off at the base of the animal tree of life, possess an outstanding capacity to regenerate. However, the cellular and molecular mechanisms underlying this ability are unknown. We have used the ctenophore Mnemiopsis leidyi as a system to study wound healing and adult regeneration and provide some first-time insights of the cellular mechanisms involved in the regeneration of one of the most ancient extant group of multicellular animals.
\end{abstract}

Results: We show that cell proliferation is activated at the wound site and is indispensable for whole-body regeneration. Wound healing occurs normally in the absence of cell proliferation forming a scar-less wound epithelium. No blastema-like structure is generated at the cut site, and pulse-chase experiments and surgical intervention show that cells originating in the main regions of cell proliferation (the tentacle bulbs) do not seem to contribute to the formation of new structures after surgical challenge, suggesting a local source of cells during regeneration. While exposure to cell-proliferation blocking treatment inhibits regeneration, the ability to regenerate is recovered when the treatment ends (days after the original cut), suggesting that ctenophore regenerative capabilities are constantly ready to be triggered and they are somehow separable of the wound healing process.

Conclusions: Ctenophore regeneration takes place through a process of cell proliferation-dependent nonblastemal-like regeneration and is temporally separable of the wound healing process. We propose that undifferentiated cells assume the correct location of missing structures and differentiate in place. The remarkable ability to replace missing tissue, the many favorable experimental features (e.g., optical clarity, high fecundity, rapid regenerative performance, stereotyped cell lineage, sequenced genome), and the early branching phylogenetic position in the animal tree, all point to the emergence of ctenophores as a new model system to study the evolution of animal regeneration.

Keywords: Ctenophore, Regeneration, Wound healing, Wound epidermis, Blastema, Stem cells, Dedifferentiation, Mnemiopsis leidyi

\footnotetext{
* Correspondence: mqmartin@whitney.ufl.edu

${ }^{1}$ The Whitney Laboratory for Marine Bioscience, 9505 N, Ocean Shore Blvd,

St. Augustine, FL 32080-8610, USA

Full list of author information is available at the end of the article
}

(c) The Author(s). 2019 Open Access This article is distributed under the terms of the Creative Commons Attribution 4.0 International License (http://creativecommons.org/licenses/by/4.0/), which permits unrestricted use, distribution, and reproduction in any medium, provided you give appropriate credit to the original author(s) and the source, provide a link to the Creative Commons license, and indicate if changes were made. The Creative Commons Public Domain Dedication waiver (http://creativecommons.org/publicdomain/zero/1.0/) applies to the data made available in this article, unless otherwise stated. 


\section{Background}

Regeneration, the ability to re-form a body part that has been lost, is a widely shared property of metazoans [1]. However, the contribution of cell proliferation, the source of regenerating tissue, and the mechanisms which pattern the replaced tissues vary greatly among animals with regenerative ability, resulting in a collection of different "modes" of regeneration [2, 3]. Based on the involvement of cell proliferation, there have been described cases of regeneration in which the restoration of the missing body part is accomplished in the absence of cell proliferation, by the remodeling of pre-existing cell tissues; on the other hand, and also more common, is the strategy of regeneration which requires active cell proliferation. Cell proliferation-based regeneration can involve the production of a regeneration-specific structure, the blastema. Several different definitions of a "blastema" have been proposed depending on the model system and its regenerative strategy. For example, in amphibians, the blastema is described as an unpigmented outgrowth consisting of a mass of undifferentiated progenitor cells that forms at the wound site from where cells proliferate and differentiate to form the missing structures [4, 5]; while in planarians, the blastema is composed of post-mitotic progeny of proliferating cells that differentiate to re-form the lost tissue [6]. Given this lack of consensus around the word "blastema" and based on the biology, morphological features, and regenerative response of our organism of study, we define the regeneration blastema as a "field" of undifferentiated cells that accumulate at the wound site and are later patterned to give rise to the appropriate set of missing structures but remains agnostic about their origin or their proliferative status.

The classical example of cell proliferation-independent regeneration is provided by the freshwater cnidarian polyp Hydra, which is able to regenerate the head after decapitation through remodeling of the pre-existing tissue without a significant contribution from cell proliferation [7-11]. While documented cases of strict cell proliferation-independent regeneration are very few, most of the organisms with regenerative potential rely on cell proliferation-or a combination of both cell proliferation and tissue remodeling-to re-form lost structures. Regenerative abilities also appear to be diverse even within individual evolutionary clades. For example, regeneration of oral structures in another member of the phylum Cnidaria-Nematostella vectensis-is characterized by high levels of cell proliferation, thus differing from the cell proliferation-independent regeneration potential in Hydra [12]. In planarians, whole-body regeneration is accomplished by the proliferation of pluripotent stem cells (neoblasts), the only cells in the adult with proliferative potential, which form a mass of undifferentiated cells known as the regenerating blastema [13-15]. Annelid regeneration provides examples of both blastema-based regeneration and tissue-remodeling-based regeneration $[16,17]$, showing diversity within the Lophotrochozoa. Moreover, evidence of cell migration has been documented during regeneration of several annelid species such as the freshwater annelid Pristina leidyi [18] and the marine annelid worm Capitella teleta, in which local (proliferating cells close to the wound site) and distant (stem cell migration) sources of cells contribute to the formation of the regenerating blastema [19]. Evidence of cell migration during regeneration is also provided by the hydrozoan Hydractinia echinata in which stem cells (i-cells) from a remote area migrate to the wound site and contribute in the formation of the blastema [20]. In vertebrates, regenerative potential is limited primarily to the structural or cellular level. Urodele amphibians are known for being the only vertebrate tetrapods that can regenerate amputated limbs as adults. Similar to the previous examples of cell proliferation-based regeneration, they require cell proliferation and the formation of a blastema. However, the urodele blastema is not generated from or composed of cells of a single type, but consists of a heterogeneous collection of lineage-restricted progenitors [21].

Among the animals with impressive whole-body regenerative capabilities are lobate ctenophores (comb jellies), fragile holopelagic marine carnivores that represent one of the oldest extant metazoan lineages. Ctenophora is the Latin for "comb bearer," referring to eight longitudinally oriented rows of locomotory ctene (or comb) plates which they coordinately beat to propel through the water column. Ctenphores possess a highly unique body plan characterized by a biradial symmetry (with no planes of mirror symmetry) and two epithelial layers: the ectoderm and the endoderm, separated by a thick mesoglea mostly composed of extracellular matrix, but also containing several types of individual muscle and mesenchymal cells. The oral-aboral axis is their major body axis, and it is characterized by the mouth at one (oral) pole and the apical sensory organ containing a statocyst at the opposite (aboral) pole. Most ctenophores possess a pair of muscular tentacles that bear specialized adhesive cells called colloblasts, used to capture prey [22] (Fig. 1c). One of the best studied species of ctenophores is the lobate ctenophore Mnemiopsis leidyi, which is emerging as a new model system in evolutionary-developmental biology [23-28]. M. leidyi's life cycle is characterized by a rapid development including a highly stereotyped cleavage program and two adult stages: the juvenile tentaculate cydippid, distinguishable for having a pair of long branching tentacles (Fig. 1a, b), and the larger lobate adult form which possesses two oral feeding lobes. A particular feature of ctenophore embryogenesis is that they undergo mosaic development, meaning that embryos cannot compensate for cells/ 


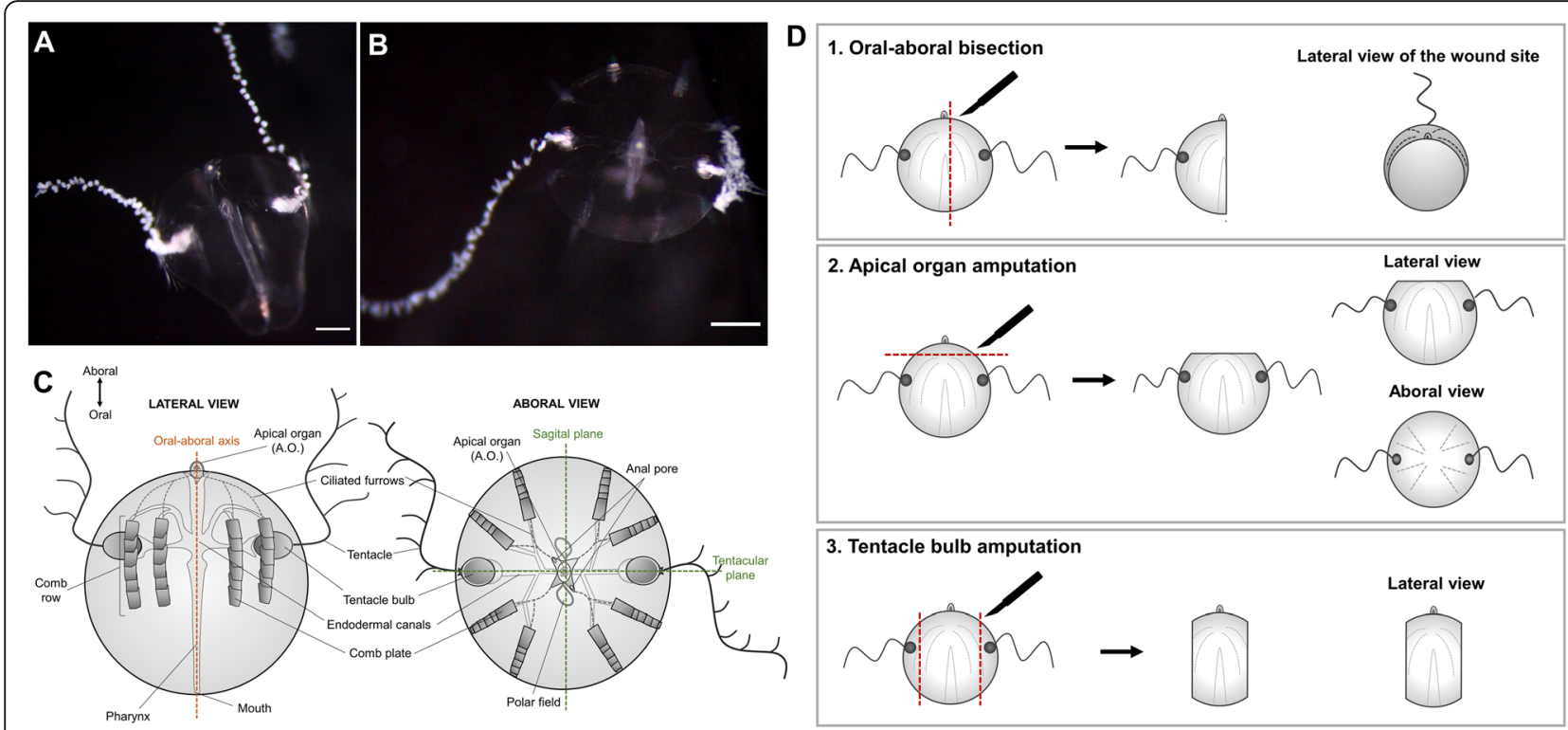

Fig. 1. Cydippid stage of Mnemiopsis leidyi and animal surgeries. a Lateral view of a M. leidyi cydippid. b Aboral view of a M.leidyi cydippid. Scale bars $=100 \mu \mathrm{m}$. $\mathbf{c}$ Schematic representation of the body plan of a cydippid stage in lateral and aboral views. $\mathbf{d}$ Diagrams showing the three types of animal surgeries performed in this study and the views presented for each one

structures derived from cells killed or isolated during early development. If blastomeres are separated at the two-cell stage, each will generate a "half animal," possessing exactly half of the normal set of adult features [29, 30]. This lack of ability to replace missing parts during embryogenesis contrasts with the outstanding capacity to regenerate as adults. Both the tentaculate larval and lobate adult life stages of $M$. leidyi readily regenerate and are capable of wholebody regeneration from only a single body quadrant [30].

It has been known for well over 80 years that ctenophores have the capacity to replace missing body parts [30-33] but the cellular and molecular mechanisms underlying this ability are poorly understood. Is cell proliferation required for ctenophore regeneration? Is any kind of blastema-like structure formed during regeneration? What is the source and nature of cells that contribute to the regenerated structures? What is the role of the wound epidermis in regulating the future regenerative outcome? We have studied wound healing and adult regeneration in the ctenophore Mnemiopsis leidyi and show that cell proliferation is activated at the wound site several hours after wound healing is complete and is indispensable for the regeneration of all the structures of the cydippid's body. Wound healing occurs normally in the absence of cell proliferation forming a scar-less wound epithelium only a few hours after amputation. In both animals cut in half along the oral-aboral axis and those in which the apical organ is removed, anlage of all missing structures occurs within $24-48 \mathrm{~h}$ and complete replacement of all cell types by $72 \mathrm{~h}$ after the injury. No blastema-like structure is generated; rather, cells accumulate at the correct location of missing structures and differentiate in place. EdU (5-ethynyl-2'-deoxyuridine) labeling shows that in uncut animals the majority of cell divisions occur in the tentacle bulbs where the tentacles are continuously growing. In surgically challenged animals, cell division is stimulated at the wound site between 6 and $12 \mathrm{~h}$ after injury and continues until $72 \mathrm{~h}$ after injury. EdU pulse and chase experiments after surgery together with the removal of the two main regions of active cell proliferation suggest a local source of cells in the formation of missing structures (Additional file 2). Although the appearance of new structures is completely dependent on cell division, surprisingly, the ability to regenerate is recovered when exposure to cell-proliferation blocking treatment ends, suggesting that the onset of regeneration is constantly ready to be triggered and it is somehow temporally separable from the wound healing process. This study provides some first-time insights of the cellular mechanisms involved in ctenophore regeneration and paves the way for future molecular studies that will contribute to the understanding of the evolution of the regenerative ability throughout the animal kingdom.

\section{Results}

Whole-body regeneration in Mnemiopsis leidyi cydippids Although the regenerative response has been studied previously in $M$. leidyi [23, 30-33], we first characterized the sequence of morphogenic events during cydippid wound healing and regeneration to provide a baseline for further experimental investigations. For this, two 
types of surgeries-representing the replacement of all the structures and cell types of the cydippid's body (e.g., apical organ, comb rows, tentacle bulbs, and tentacles) were performed: (1) bisection through the oral-aboral axis keeping the piece with an intact apical organ which required the remaining piece to regenerate four comb rows and a tentacle apparatus (bisected cydippids with a complete intact apical organ regenerate into whole animals in a higher percentage of the cases compared to bisected animals with a half apical organ) [30] and (2) apical organ amputation consisting in the removal of the apical organ, requiring the remaining piece to regenerate dome cilia, balancing cilia, lithocytes, polar fields, and neural cells of the apical organ floor (Fig. 1d). The timing and order of formation of missing structures was assessed by in vivo imaging of the regenerating animals at different time points along the regeneration process.

\section{Wound healing}

To assess the mechanism of wound healing, juvenile cydippids were punctured generating a small epithelial gap (Fig. 2a) (imaging of larger wound healing events provided to be too difficult to document visually). Within minutes after puncture, the edges of the cells lining the gap increased their thickness indicating the start of the wound closure. The next phase of wound closure was characterized by the migration of a small number of cells coming from deep levels of the mesoglea (underneath the epithelial layer) to the edges of the wound (Fig. 2b, Additional file 1). Interestingly, while the migration of cells from the mesoglea to the wound site was quite evident, the migration of epithelial cells across the wounded area was not observed. Once the migrating deep cells adhered to the edges of the gap, they started to extend spike-shaped cytoskeleton extensions (filopodia) laterally towards the adjacent cells. The diameter of the gap was progressively reduced as the connections between filopodia of marginal cells pulled the edges of the wound together (Fig. 2c). When the diameter of the gap was significantly reduced, the cells at the margin of the gap started to extend filopodia not only to adjacent cells, but also to cells from the opposite edge of the wound. At this stage, multiple filopodia were detected emerging from a single cell (Fig. 2d). Filopodia from all the edges of the wound eventually met forming a network of filaments that sealed the gap (Fig. 2e) resulting in a scar-free epithelium within approximately $1-1.5 \mathrm{~h}$ after the procedure.

\section{Events during half-body regeneration of Mnemiopsis leidyi cydippids following bisection through the oral-aboral axis}

Cydippid stage animals were bisected through the oralaboral axis with one half retaining the intact whole apical organ. Bisected cydippids containing half of the set
A

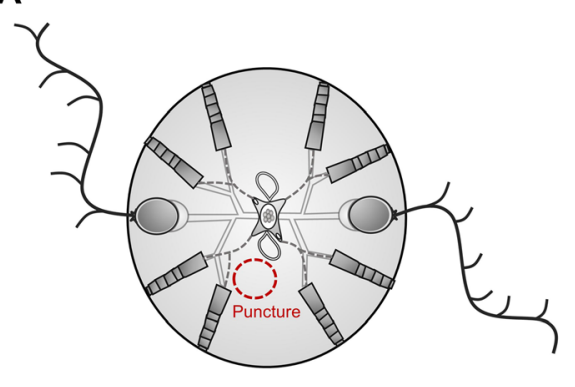

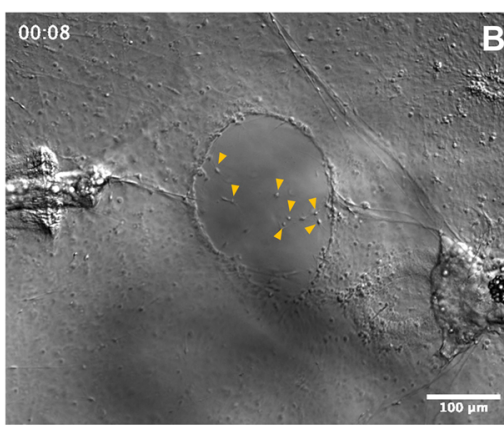

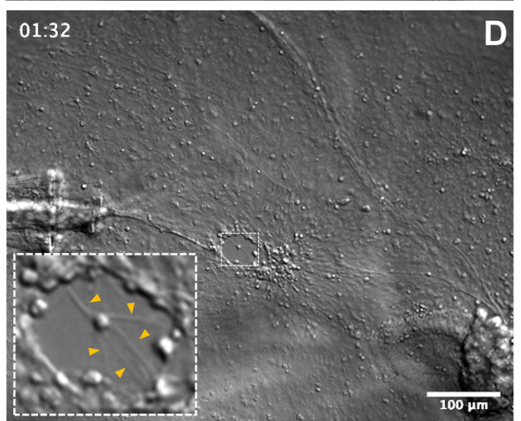

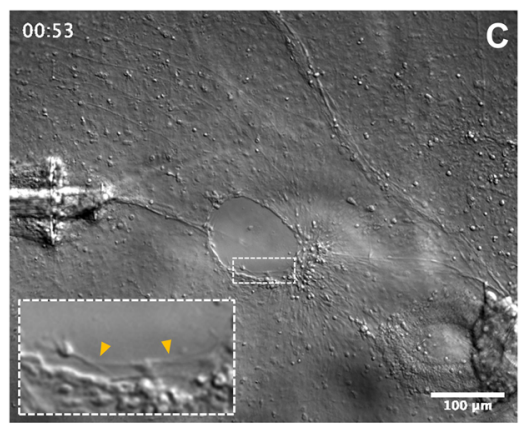

02:00

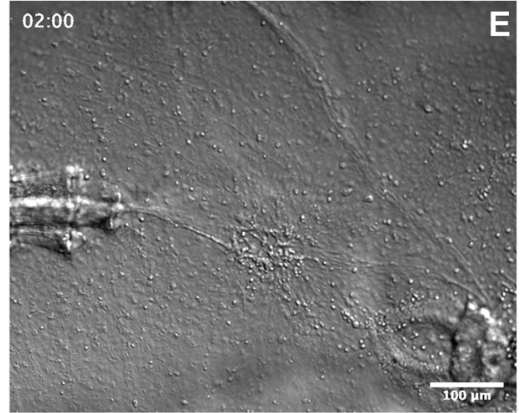

Fig. 2. Wound healing by filopodia-dependent cell crawling. a Schematic representation of the puncture assay. b-e DIC images of the main phases of wound closure (see Additional file 1 for the time-lapse video corresponding to these images). $\mathbf{b}$ Cells from the mesoglea (yellow arrow caps) migrate upwards and adhere to the edges of the wound. c Marginal cells of the wound gap extend filopodia to the adjacent cells pulling the edges of the wound together. The inset shows a closer look to the cells at the edge of the wound, and yellow arrow caps point to the filopodia. $\mathbf{d}$ When the diameter of the gap is considerably reduced, cells of the wound edge extend filopodia towards the opposite edges of the gap. The inset shows a cell extending multiple filopodia. e Network of filopodia connecting all the edges of the wound. Timescale is in hours. Scale bars $=100 \mu m$ 
of structures present in intact cydippids (four comb rows and one tentacle) and a complete apical organ were left to regenerate in $1 \mathrm{x}$ filtered sea water $(1 \mathrm{x} \mathrm{FSW})(n>100)$ at $22^{\circ} \mathrm{C}$. Wound closure was initiated rapidly after bisection with the edges of the wound forming a round circumference that continued to reduce in diameter until meeting and was completed within $2 \mathrm{~h}$ after bisection (hab). No scar or trace of the original wound was evident after this time. About 16 hab, four ciliated furrows-which connect the apical organ with the comb rows-appeared on a surface epithelium at the aboral end of the cut site (Fig. 3b). A large mass of cells (blastema-like structure) never appeared at the cut site. Rather, accumulations of cells were detected forming the primordia of all four of the future comb rows in a deeper plane at the end of each ciliated furrow. By 24 hab, the first comb plates appeared, first in the two most external (closer to existing comb rows) comb rows and later in the two internal rows (Fig. 3c). Comb plate formation did not follow a consistent pattern initially. The correct orientation of comb plates and coordination of their beating was accomplished after a number of comb plates were formed (Fig. 3d surface, deep), as has been described previously [33]. Within 40 hab, coordinated comb plates were beating in all four regenerating comb rows and the primordia of tentacle bulb had emerged in the middle of the four comb rows. By 48 hab, regeneration of the missing structures of the cydippid body was essentially completed including the formation of the tentacle growing from the tentacle bulb (Fig. 3e). At $96 \mathrm{~h}$ after bisection, the regenerated tentacle was long enough to actively catch prey. The cut side continued to grow, and within a day or two, it was indistinguishable from the uncut side (Fig. 3f).

\section{Events during regeneration of Mnemiopsis leidyi cydippids following apical organ amputation}

Cydippids in which the apical organ was amputated were left to regenerate in $1 \mathrm{x}$ FSW $(n>100)$ at $22^{\circ} \mathrm{C}$. The cut edges of the wound met and sealed within $30-60 \mathrm{~min}$ of the operation, and the lesion was completely healed around $2 \mathrm{~h}$ post amputation (hpa). Between 6 and $12 \mathrm{hpa}$, cells congregated under the wounded epithelium forming the primordia of the future apical organ (Fig. 4E-F'). Extension of the ciliated furrows from each comb row towards the wound site could be spotted around $12 \mathrm{hpa}$. Within $24 \mathrm{hpa}$, cells at the wound site started to differentiate into the floor of the apical organ and its supporting cilia (Fig. 4G-H'). At $48 \mathrm{hpa}$, all the components of the statolith, including the supporting cilia, the balancing cilia, and lithocytes, were formed (Fig. 4I-J'). At approximately $60 \mathrm{hpa}$, the complete set of structures forming the apical organ were regenerated with the

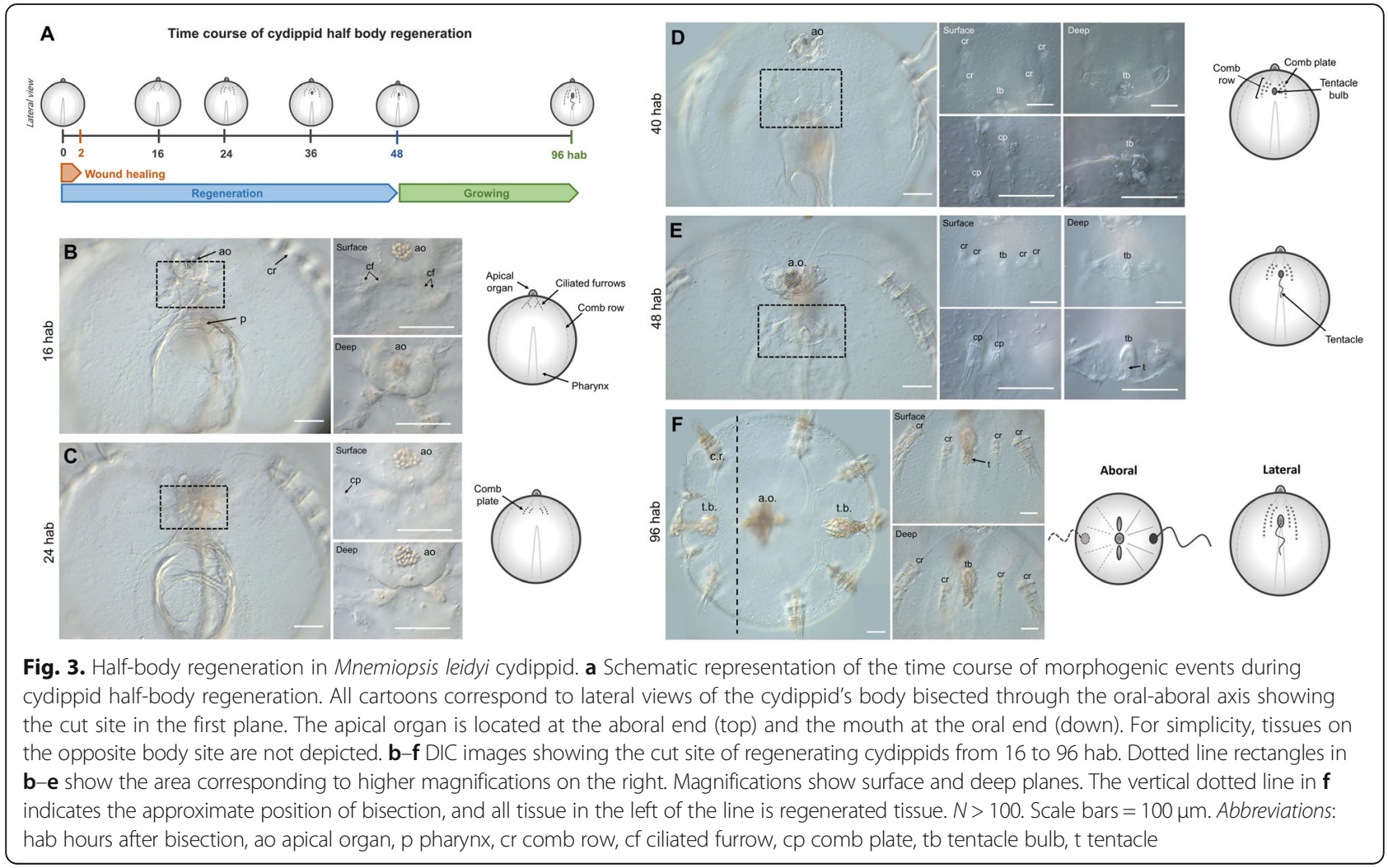




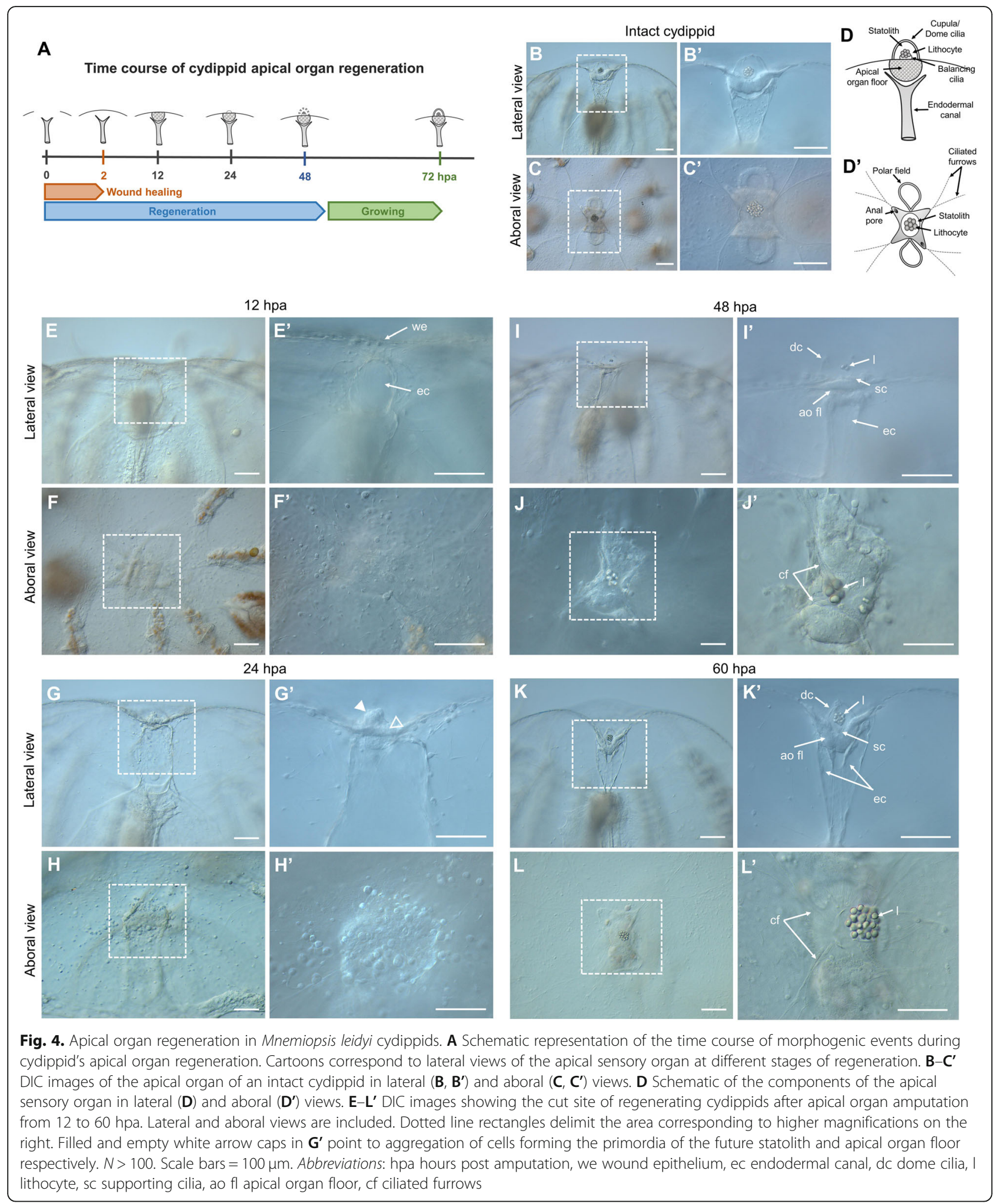

exception of the polar fields (Fig. 4K-L'). Within 3 days after surgery, the polar fields had formed, and animals were indistinguishable from control animals of the same size.

\section{Cell proliferation in intact cydippids}

To identify areas of cell proliferation in juvenile M. lei$d y i$, intact cydippids between 1.5 and $3.0 \mathrm{~mm}$ in diameter were labeled with the thymidine analog 5 -ethynyl- 
20-deoxyuridine (EdU), which is incorporated into genomic DNA during the $S$ phase of the cell cycle [27, 3436] (Fig. 5A). Cydippids incubated with EdU during a 15-min pulse showed a pattern of cell division characterized by two main regions of active cell proliferation corresponding to the two tentacle bulbs (Fig. 5B, B'). Higher magnifications of these structures showed EdU staining specifically concentrated at the lateral and median ridges of the tentacle bulb. Two symmetrical populations of densely packed cells were observed at the aboral extremity of the lateral ridges, previously characterized by Alié et al. [36] as the aboral/external cell masses (a.e.c.) (Fig. 5C'). EdU labeling was also found in some cells of the apical organ and few isolated cells along the pharynx and under the comb rows $(n=20$, Fig. 5B-D').
To detect dividing cells in $\mathrm{M}$ phase of the cell cycle, we performed anti-phospho-histone 3 (anti-PH3) immunolabelings in intact cydippids. The spatial pattern and distribution of $\mathrm{PH} 3$ labeling closely matched the one described for EdU incorporation, although PH3+ cells were always about $10 \%$ less numerous than the EdUlabeled cells, suggesting that the duration of the $M$ phase is much shorter than the $\mathrm{S}$ phase $(n=10$, Fig. 5B", C", D").

In order to track the populations of proliferating cells over time in intact animals, we performed EdU pulsechase experiments consisting in a 15-min EdU incubation (pulse) and a chase of different times followed by visualization (Fig. 5A). After a 24-h chase, the pools of proliferating cells had migrated from the tentacle bulb

A

EdU pulse-chase experiment
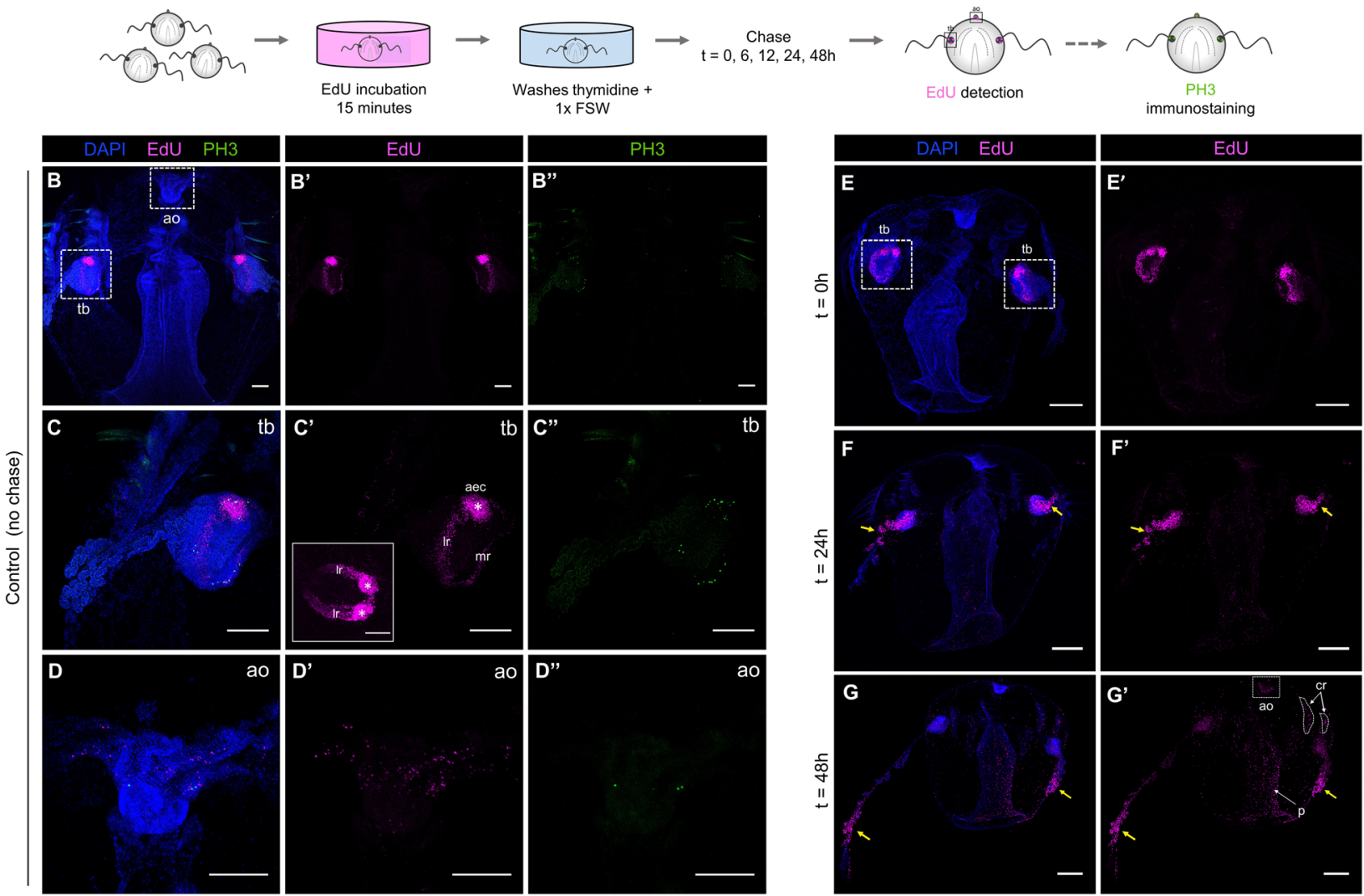

Fig. 5. Cell proliferation in intact cydippids. A Schematic of the EdU pulse-chase experiment and PH3 immunostaining in intact cydippids. B-D' Confocal stack projections of whole intact cydippids oriented in a lateral view. White dotted rectangles in $\mathbf{B}$ delimit the tentacle bulb (tb) $\left(\mathbf{C}-\mathbf{C}^{\prime \prime}\right)$ and apical organ (ao) (D-D") structures showed in higher magnification at the bottom. Nuclei of S-phase cells are labeled with EdU (magenta), M-phase cells are immunostained with anti-phospho-histone 3 (PH3) (green), and all nuclei are counterstained with DAPI (blue). Note that both markers of cell proliferation (EdU and PH3) show the same pattern of distribution along the cydippid's body. The inset in $\mathbf{C}^{\prime}$ shows an aboral view of the tentacle bulb after EdU staining. White asterisks in $\mathbf{C}^{\prime}$ point to the symmetrical populations of intense cell proliferation referred to as aboral/external cell masses (aec). $\mathbf{E}-\mathbf{G}^{\prime}$ Confocal stack projections of whole intact cydippids oriented in a lateral view. The time of the chase is listed at the top of the columns, and the labeling corresponding to each panel is listed to the left of the rows. Nuclei of S-phase cells are labeled with EdU (magenta) and all nuclei are counterstained with DAPI (blue). Note that EdU+ cells migrate from the tentacle bulb to the most distal end of the tentacle (yellow arrows). See Additional file 2 for further detail of EdU pulse-chase experiment in the tentacle bulb. Scale bars $=100 \mu \mathrm{m}$. Abbreviations: ao apical organ, tb tentacle bulb, aec aboral/external cell masses, Ir lateral ridge, mr medial ridge, cr comb row 
through the proximal region of the tentacles, although some EdU+ cells were still detected at the tentacle sheath. Increased labeling of nuclei in the apical organ, pharynx, and comb rows was also observed $(n=10$, Fig. 5E-F'). Following a 48-h chase, the population of proliferating cells that was originally in the tentacle bulbs at the time of labeling had migrated to the most distal end of the tentacles, but only a few cells associated with the tentacle bulb showed long-term EdU retention, suggesting that there is a resident population of slowly dividing stem cells in the tentacle bulb as previously reported by Alié et al. [36]. The number of EdU+ nuclei along the pharynx, apical sensory organ (specifically in the apical organ floor), and comb rows was considerably increased compared to the 24-h chase condition $(n=10$, Fig. 5G, G'), suggesting that there are either small populations of EdU-labeled cells restricted to those areas that had proliferated during the chase period, or that cells migrated in to those regions from regions of high mitotic density, or a combination of both events. Attempts to quantify and compare brightness levels of EdU-positive cells to infer additional rounds of cell division during the chase period proved inconclusive (data not shown).

\section{Cell proliferation is activated during ctenophore regeneration}

In order to determine the role of cell proliferation in ctenophore regeneration, we performed a series of EdU experiments in regenerating cydippids. A 15-min exposure to EdU at different times after surgical cutting was evaluated after two types of surgeries that required different regenerative responses: a bisection through the oral-aboral axis and an apical organ ablation (Figs. 6A and 7A). The dynamics of cell proliferation at the wound site were quantified by calculating the ratio of EdU+ nuclei to total nuclei (DAPI stained) at different time points following surgery (Figs. 6B and 7B).

Following oral-aboral bisection, EdU+ nuclei were first detected at the wound site between 6 and $12 \mathrm{~h}$ after bisection (hab). There was some variability in the presence of EdU+ nuclei at 6 hab-with some specimens having fewer EdU+ nuclei at the wound site than others; however, the presence of EdU+ cells was consistent in all the analyzed individuals by $12 \mathrm{hab}$. The few EdU+ cells at the early stages were scattered all along the cut site, but no aggregation of cells was observed $(n=7$, Fig. $6 \mathrm{C}-\mathrm{C}$ ). The number of EdU+ nuclei at the wound site slightly increased between 12 and 24 hab reaching a maximum at 24 hab (Fig. 6B), when EdU+ cells appeared concentrated in discrete areas corresponding to the forming primordia of the regenerating tissues (the tentacle bulb and comb rows) ( $n=27$, Fig. 6D-D"). By 48 hab, the percentage of EdU+ nuclei had decreased as the cells started to differentiate into the final structures.
EdU+ nuclei appeared confined into the regenerating comb rows and tentacle bulb, already distinguishable by nuclear staining $(n=12$, Fig. $6 \mathrm{E}-\mathrm{E} ")$. At 72 hab, the number of EdU+ nuclei in the comb rows was considerably reduced and these were concentrated at the oral end of the regenerating structures, where oral portions of structures are generated later than aboral regions. For example, proliferative cells were no longer detected at the aboral end of the comb rows where cells had already differentiated into comb plates. In contrast, EdU+ cells at the regenerating tentacle bulb were abundant but appeared organized at the aboral extremity forming the two symmetrical populations of cells characteristic of the structure of the tentacle bulb $\left(n=15\right.$, Fig. $\left.6 \mathrm{~F}-\mathrm{F}^{\prime}\right)$. By 96 hab, when major repatterning events of regeneration were completed, EdU+ cells were only detected at the regenerated tentacle sheath forming the pattern of cell proliferation previously described in the tentacle bulbs of intact cydippids (Fig. 5) ( $n=5$, Additional file 3A-A"). In combination with EdU incorporation experiments, anti-PH3 immunostaining was performed at selected time points following bisection. $\mathrm{PH} 3+$ cells were detected in the regenerating comb rows and tentacle bulb at 24 hab and 48 hab (Additional file $4 \mathrm{~A}-\mathrm{B}$ ") consistent with the EdU incorporation pattern, although the number of $\mathrm{PH} 3+$ cells was always less numerous than the EdU+ cells.

EdU labeling was also detected at the wound site of regenerating cydippids after apical organ amputation. Consistent with the oral-aboral bisection surgeries, EdU+ cells were first detected at $12 \mathrm{hpa}$ suggesting that the start of the cell proliferation response occurred between the 6 and 12 hpa time points. A peak of cell proliferation was also observed at 24 hpa (Fig. 7B), with EdU+ cells localized at the primordia of the apical organ, specifically in the apical organ floor and in the surrounding tissue including the regenerating comb rows adjacent to the cut site ( $n=15$, Fig. 7E-F"). The number of proliferating cells slightly decreased at 48 hpa when EdU+ cells were concentrated in the regenerating apical organ and were no longer found in the tissues near the wound site $\left(n=20\right.$, Fig. $\left.7 \mathrm{G}-\mathrm{H}^{\prime \prime}\right)$. By $72 \mathrm{hpa}$, the EdU+ nuclei were scarce and localized mostly along the polar fields in some specimens, while EdU+ nuclei were completely absent in other individuals at the same time point $(n=6$, Additional file $3 \mathrm{~B}-\mathrm{C}$ '). Anti-PH3 immunostaining showed the presence of M-phase cells at the regenerating area at both $24 \mathrm{hpa}$ and $48 \mathrm{hpa}$. Similar to half-body regeneration, the pattern of anti-PH3 was consistent with the EdU labeling with $\mathrm{PH} 3+$ cells being more numerous at 24 hpa than 48 hpa. However, it should also be noted that as in all of our other observations, the number of $\mathrm{PH} 3+$ cells at any given time point was always lower compared to the EdU+ cells (Additional file 4C-D'). 


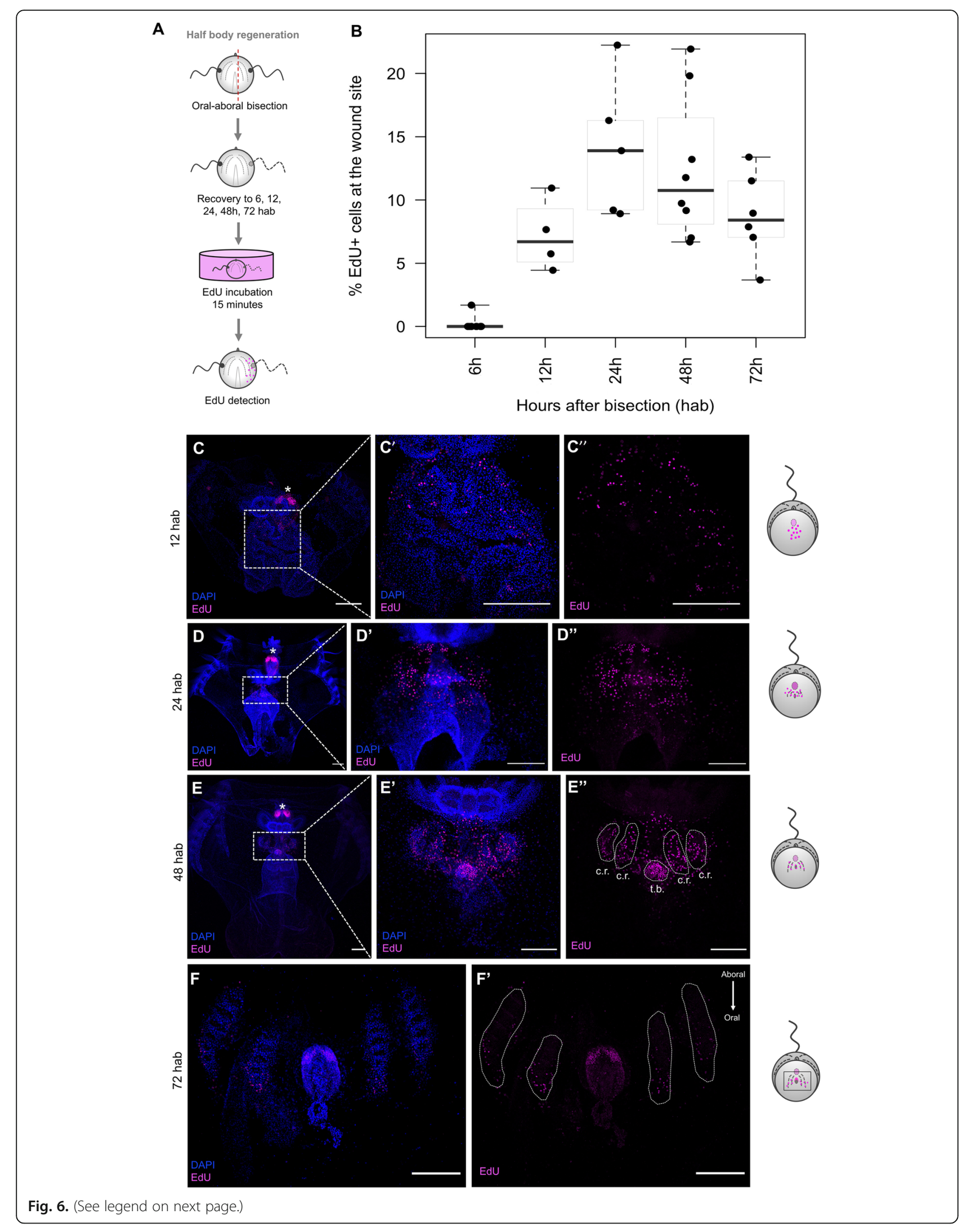


(See figure on previous page.)

Fig. 6. Cell proliferation during half-body regeneration. A Schematic of the EdU incorporation experiment in cydippids bisected through the oralaboral axis. B Box plot showing the levels of cell proliferation at the wound site at different time points after bisection. The thick horizontal bars indicate the median values. Each dot represents one individual. $\mathbf{C}-\mathbf{F}^{\prime}$ Confocal stack projections of bisected cydippids through the oral-aboral axis oriented in a lateral view showing the cut site in the first plane. The time following bisection is listed to the left of the rows. Nuclei of S-phase cells are labeled with EdU (magenta), and all nuclei are counterstained with DAPI (blue). The pattern of EdU labeling corresponding to each time point is shown in a cartoon on the right of the rows. Dotted line rectangles in $\mathbf{C}, \mathbf{D}$, and $\mathbf{E}$ show the area corresponding to higher magnifications on the right. White dotted lines in $\mathbf{E}^{\prime \prime}$ and $\mathbf{F}^{\prime}$ delimit the area corresponding to the regenerating comb rows and tentacle bulb. White asterisks point to tentacle bulbs of the uncut site. Note that EdU+ cells at $72 \mathrm{hpa}\left(\mathbf{F}^{\prime}\right)$ are located at the oral end of the regenerating comb rows and no $\mathrm{EdU}+$ cells are detected at the aboral end where cells are already differentiated. Scale bars $=100 \mu \mathrm{m}$. Abbreviations: hab hours after bisection, $\mathrm{cr}$ comb row, tb tentacle bulb

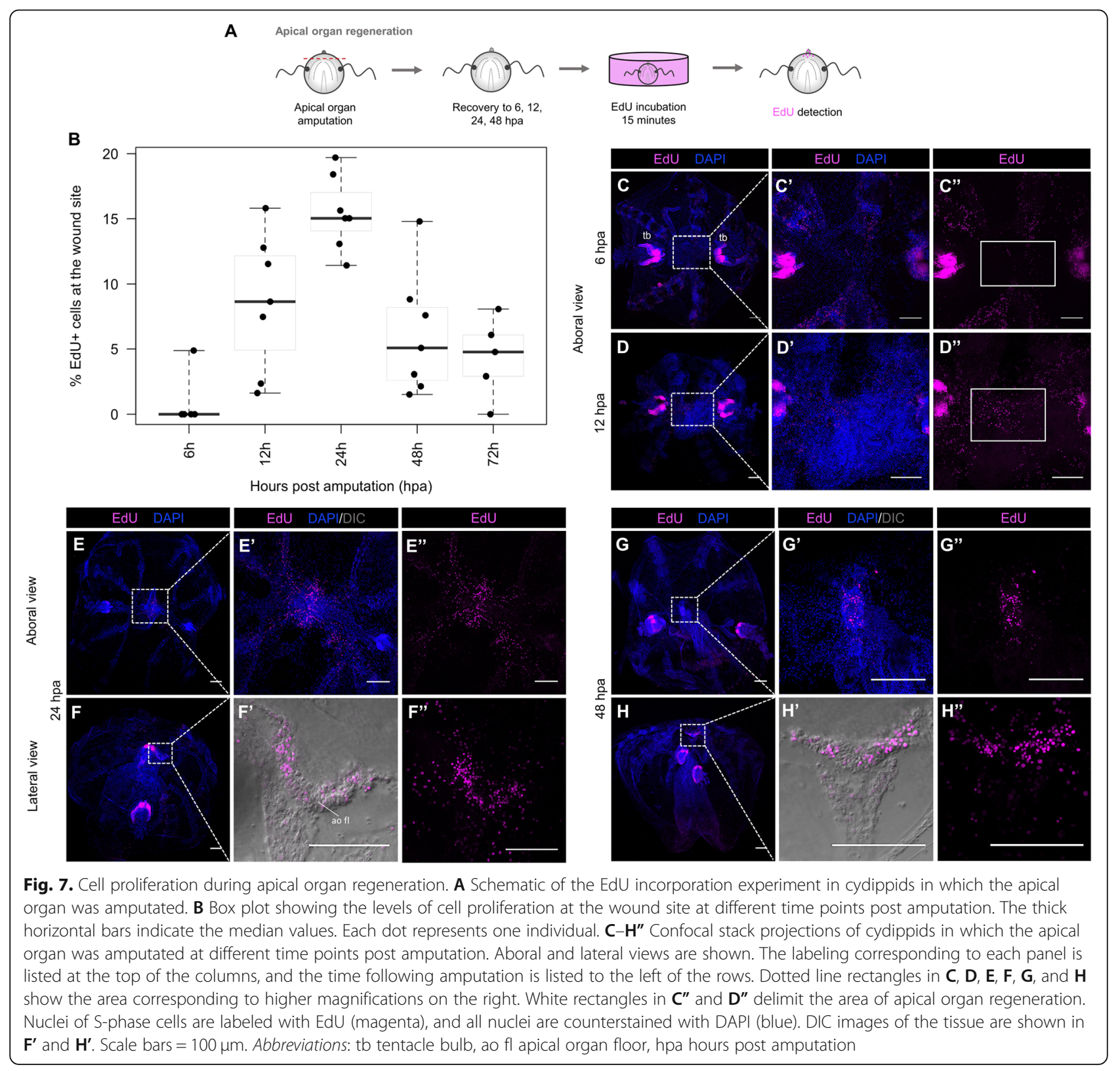


Interestingly, for both types of surgeries, proliferating cells were not organized in a compacted mass of "blastema-like" cells from were new tissue is formed. In contrast, proliferating cells were very few and scattered throughout the wound site at early time points after surgery-when a blastema is normally formed in animals with cell proliferation-based regeneration-and appeared more abundant and directly confined at the correct location of missing structures at later stages of regeneration, where they differentiated in place.

\section{Cells participating in the regenerative response appear to arise locally}

To investigate the source of cells that contribute to the formation of new tissue during ctenophore regeneration, we performed a series of EdU pulse and chase experiments in regenerating cydippids. This technique has been successfully used in different model systems as a strategy to indirectly track populations of proliferating cells and determine their contribution to the formation of new structures $[19,37]$. With the aim of determining whether cells proliferating before amputation contribute to the formation of new tissues, uncut cydippids were incubated in EdU, which was incorporated into cells undergoing the $\mathrm{S}$ phase of cell cycle. After a 15-min pulse, animals were removed from EdU, and EdU incorporation was blocked ("chased") with several washes of thymidine and $1 \mathrm{x}$ FSW. Following the washes, apical organ amputations and oral-aboral bisections were performed and animals were left to regenerate in 1x FSW. The location of EdU+ cells was subsequently visualized at 24 and $48 \mathrm{~h}$ after injury. In combination with EdU detection, an immunostaining against $\mathrm{PH} 3$ was performed in order to detect cells that were actively dividing in the animal immediately before fixation (Fig. 8A).

No EdU+ cells were detected at the wound site at $24 \mathrm{~h}$ $(n=30)$ nor $48 \mathrm{~h}(n=10)$ after bisection (Fig. 8B-C"). EdU labeling at the tentacle bulb resembling the pattern of cells migrating from the tentacle bulb distally along the tentacle previously described (Fig. 5F-F') confirmed that the chase worked properly (Fig. 8B). Moreover, the presence of $\mathrm{PH} 3+$ cells were observed at the regenerating area indicating active cell division at the moment of fixation (Fig. 8B", C"). Following apical organ amputation, few EdU+ nuclei were detected at the area of apical organ regeneration although the EdU signal was very weak, suggesting that these cells were the result of multiple rounds of division $(n=13$, Fig. 8D-D"). After a 48$\mathrm{h}$ chase, few bright EdU+ nuclei were detected at the apical organ suggesting that S-phase cells from the uncut tissue might contribute to the formation of the apical sensory organ at later stages of regeneration $(n=12$, Fig. 8E-E"). Presence of $\mathrm{PH} 3+$ cells at the regenerating apical organ confirmed active cell division at the apical organ area (Fig. 8E', E"). Taken together, these results show a minor contribution of proliferative cells originating in distant pre-existing proliferative tissue such as the tentacle bulbs to the formation of new structures.

Expression patterns determined through in situ hybridization have reveled spatially restricted expression of the stem cell gene markers Piwi, Vasa, Nanos, and Sox within areas of cell proliferation including the tentacle bulbs, in both juvenile cydippid and adult stages [27, 28, $36]$. On the other hand, the ctenophore group of Beroids does not possess tentacles at any stage of their life cycle and they are the only group of ctenophores that have lost the ability to regenerate [24]. Based on these observations, it was hypothesized that the tentacle bulbs served as putative "stem cell niche" source of new cells involved in the regeneration process [23]. To test this hypothesis, we surgically removed both tentacle bulbs from juvenile cydippids and assessed their ability to regenerate. Two days after amputation all animals had regenerated all the cell types of the tentacle bulb $(n>$ 100, Fig. 9A-C'). EdU labeling at different time points after amputation showed activation of cell proliferation during tentacle bulb regeneration, consistent with the other two types of surgeries analyzed. EdU+ nuclei were first detected at the distal end of the endodermal canals that connect the tentacles to the gastrovascular system at $18 \mathrm{hpa}(n=10$, Fig. 9E-E"). At $24 \mathrm{hpa}$, the number of EdU+ cells had increased, and they were mainly organized forming the primordia of tentacle bulbs although some EdU+ cells were still detected at the tip of the endodermal canal connecting to the tentacle bulbs in formation ( $n=20$, Fig. 9F-F”). By 48 hpa, EdU+ nuclei appeared organized in the characteristic pattern of intact tentacle bulbs (Fig. 5B', C'), and they were not detected at the endodermal canals any more $(n=20$, Fig. 9G-G"). In addition, animals in which both tentacle bulbs and apical organ were removed were able to regenerate all the missing structures (data not shown). These data argue strongly that the tentacle bulbs are not the source of multipotent stem cells required for the successful regenerative response in tentaculate ctenophores and point to a local source of cells in the formation of new structures.

\section{There is recruitment of slowly dividing cells at the regenerating structures}

After having discarded the tentacle bulbs as the "stem cell niche" source of new cells for the regeneration of all missing structures, we questioned whether there is a population of slowly dividing cells scattered among the ctenophore body which get stimulated after injury and contribute to the regenerative process. In order to target for slowly cycling cells, we performed a long pulse-chase experiment consisting of a 2-h EdU incubation pulse (in 


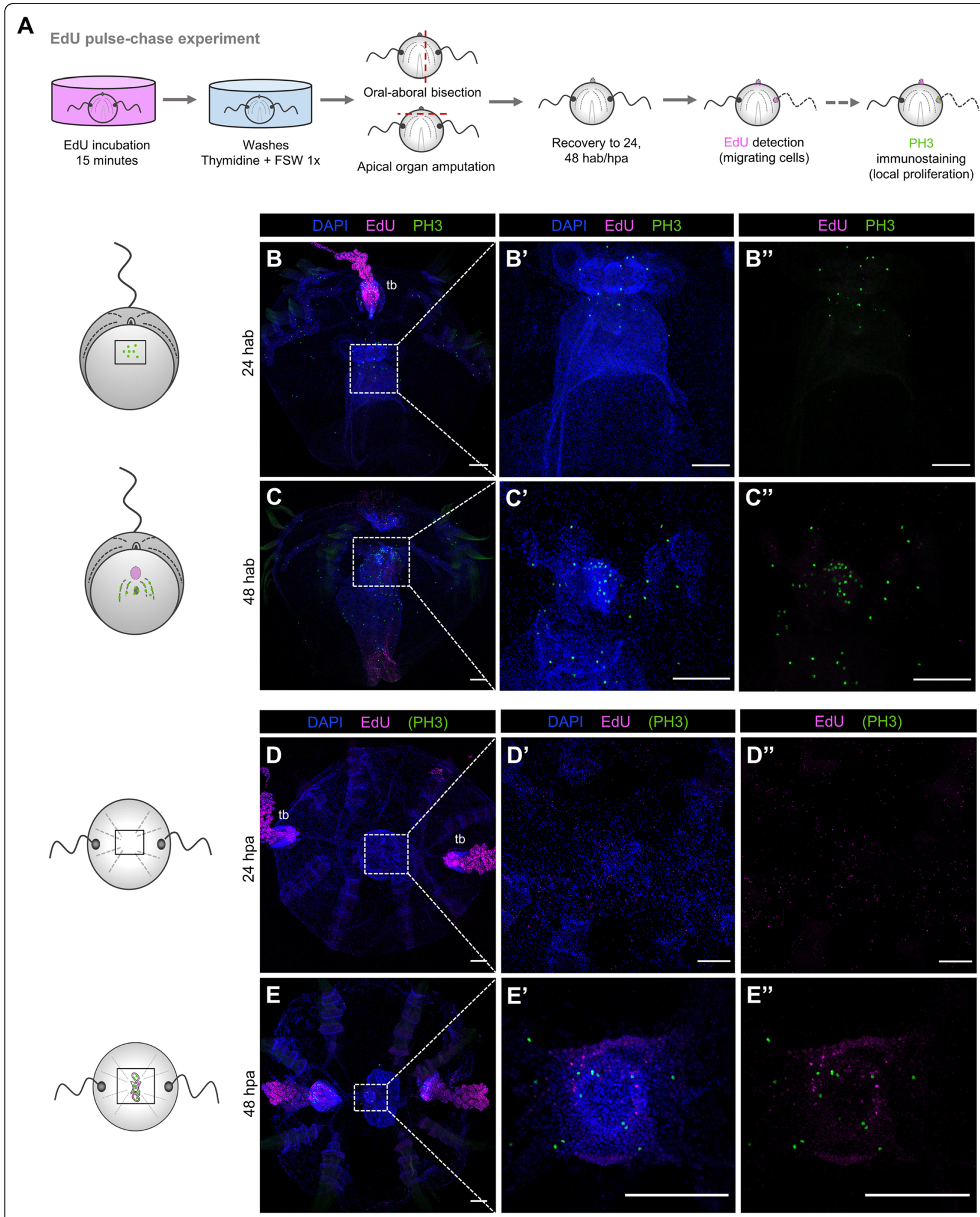

Fig. 8. (See legend on next page.) 
(See figure on previous page.)

Fig. 8. S-phase cells derived from the main regions of cell proliferation do not contribute to the formation of new structures. A Schematic of the EdU pulse-chase experiments and PH3 immunostaining in regenerating cydippids after oral-aboral bisection and apical organ amputation. B-C" Confocal stack projections of bisected cydippids through the oral-aboral axis oriented in a lateral view showing the cut site in the first plane. DE" Confocal stack projections of cydippids in which the apical organ was amputated oriented in an aboral view. The labeling corresponding to each panel is listed at the top of the columns, and the time of chase is listed to the left of the rows. Nuclei of S-phase cells are labeled with EdU (magenta), M-phase cells are stained with anti-PH3 (green), and all nuclei are counterstained with DAPI (blue). Dotted line rectangles in B, C, D, and $\mathbf{E}$ show the area corresponding to higher magnifications on the right. The pattern of EdU and PH3 staining is shown in cartoons on the left. Scale bars $=100 \mu \mathrm{m}$. Abbreviations: hab hours after bisection, hpa hours post amputation, tb tentacle bulb

contrast to the 15-min EdU pulse performed in previous pulse-chase experiments) followed by a 5-day chase (Fig. 10A).

EdU+ cells just after the 2-h EdU pulse were found very densely compacted in two main areas corresponding to the tentacle bulbs (Fig. 10D, D', G, G'), and sparser although also abundant in the apical sensory organ (specifically the apical organ floor) (Fig. 10C, C', G, and G'and Additional file 8), under the comb rows (Fig. 10I, I') and the pharynx (Fig. 10F') $(n=22$, Fig. 10B-I). This EdU labeling is consistent with the EdU pattern observed in intact cydippids after a 15-min EdU pulse (Fig. 5B, B'); however, in contrast to the 15-min pulse EdU pattern, the amount of EdU+ cells detected at the apical organ, comb rows, and pharynx was considerably higher after the 2-h EdU incubation. Moreover, EdU+ cells were also detected through the epidermal surface (Additional files 6 and 7) and endodermal canals (Additional file 9), locations where EdU+ cells were not detected after the 15-min EdU pulse. After the 5-day chase, EdU+ cells were located around the apical organ, pharynx, comb rows, and epidermis but they were no longer detected at the tentacle bulbs nor the tentacles ( $n=21$, Fig. 10J-O' and Additional files 10 and 11). This result is consistent with the idea that a population of protected slowly dividing cells does not exist confined in a concrete location (tentacle bulbs) but, rather, slowly cycling cells are found scattered among several structures of the cydippid body.

To determine whether this population of slowly dividing cells contributes to the process of regeneration, we amputated the apical organ structure from cydippids exposed to the 2-h EdU pulse and 5-day chase. The location of EdU+ cells was subsequently visualized at $24 \mathrm{hpa}$ (Fig. 10A). EdU+ cells were detected at the regenerating apical organ $24 \mathrm{~h}$ post amputation ( $n=10$, Fig. $\left.10 \mathrm{P}-\mathrm{S}^{\prime}\right)$ indicating a contribution of slowly dividing cells originated at the pre-existing tissue to the regenerating structure.

\section{Cell proliferation is strictly required for ctenophore regeneration}

Having demonstrated that cell proliferation is activated during ctenophore regeneration, our next aim was to address the requirement of cell proliferation in the process of regeneration. Juvenile cydippids were exposed to hydroxyurea (HU) treatments, a drug that inhibits cell proliferation by blocking the ribonucleotide reductase enzyme and thereby preventing the $\mathrm{S}$ phase of cell cycle [38]. We first performed a dose-response test experiment in order to set the working concentration of $\mathrm{HU}$ in which animals could be continuously incubated during the complete period of regeneration with no significant disruption of their fitness. Concentrations of 20, 10, and $5 \mathrm{mM}$ HU were tested over a 72-h time course. Incubations in 20 and $10 \mathrm{mM}$ HU were toxic and caused the degeneration and eventually death of most of the animals during the first $24 \mathrm{~h}$ of incubation (data not shown). Incubations in $5 \mathrm{mM} \mathrm{HU}$ were much less harmful; cydippids maintained a good condition, swimming normally with no cell death over the 72-h time course. We therefore decided to set $5 \mathrm{mM} \mathrm{HU}$ as the working concentration for the cell proliferation inhibitor experiments. We then assessed the efficacy of that drug concentration in blocking cell proliferation in intact cydippids. Intact cydippids were incubated in $5 \mathrm{mM} \mathrm{HU}$ for 24 and $72 \mathrm{~h}$ and then incubated for $15 \mathrm{~min}$ with EdU as previously described (Additional file 12A). At $24 \mathrm{~h}$ of $\mathrm{HU}$ incubation, there was no detectable incorporation of EdU as compared with control cydippids, which showed the characteristic pattern of cell proliferation described in Fig. 5 (Additional file 12B-C'). Inhibition of cell proliferation was maintained $72 \mathrm{~h}$ after continuous $\mathrm{HU}$ incubation, as shown by the total absence of EdU+ cells in treated cydippids (Additional file 12D-E'). Finally, we evaluated the effect of the drug during regeneration in dissected cydippids. Cydippids bisected through the aboral-oral axis and cydippids in which the apical organ was amputated were exposed to a continuous incubation of $5 \mathrm{mM}$ HU from 0 to $72 \mathrm{~h}$ after surgery. None of the bisected cydippids had regenerated at $72 \mathrm{~h}$ following $\mathrm{HU}$ treatment ( $n=75$, Fig. 11D-E'). Wound closure and healing occurred normally as shown by the continuous epidermal layer covering the wound (Fig. 11E), but no sign of formation of the missing structures (tentacle bulb and comb rows) was observed. Moreover, bisected cydippids in which HU was added 4 hab $(n=25)$-when wound healing is already completed-and 12 hab $(n=$ 


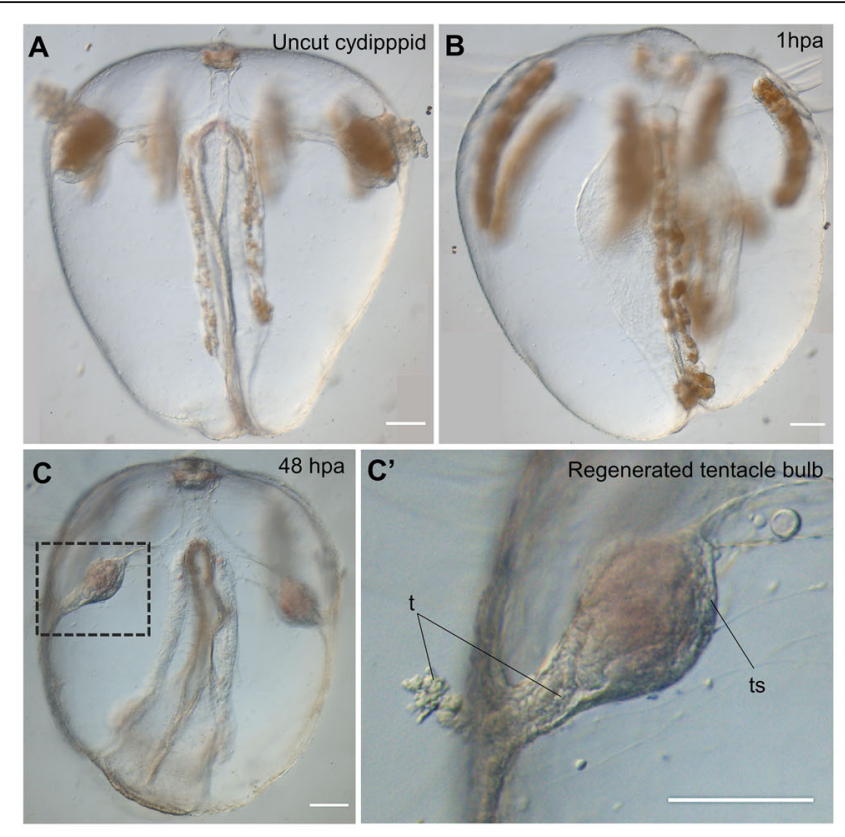

D Tentacle bulb regeneration

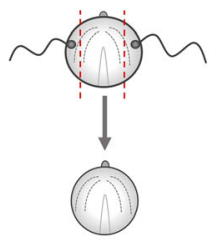

Recovery to 18

24, $48 \mathrm{hpa}$

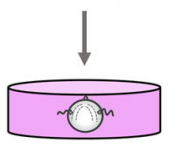

EdU incubation

15 minutes
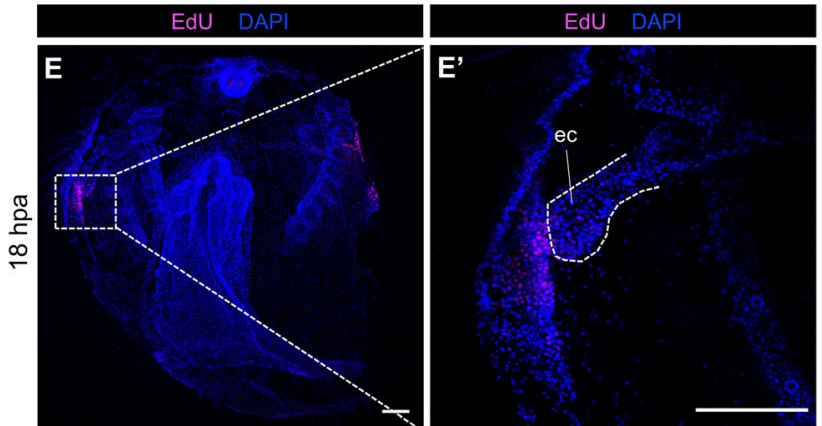

E'
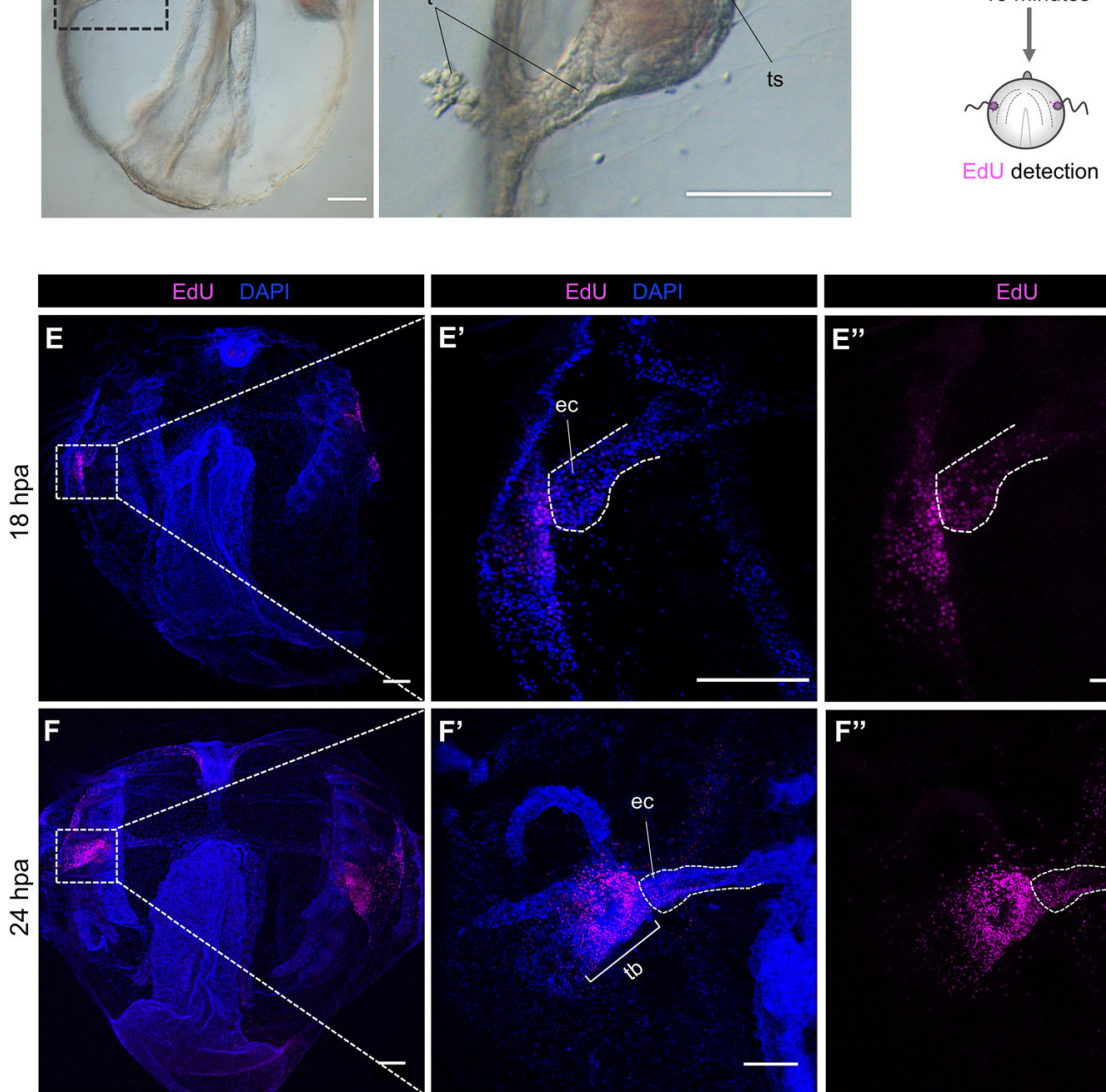

EdU detection

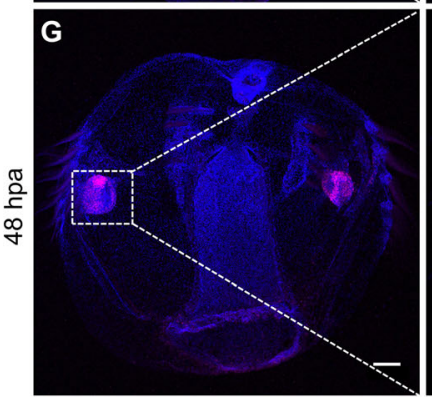

$\mathbf{G}^{\prime}$
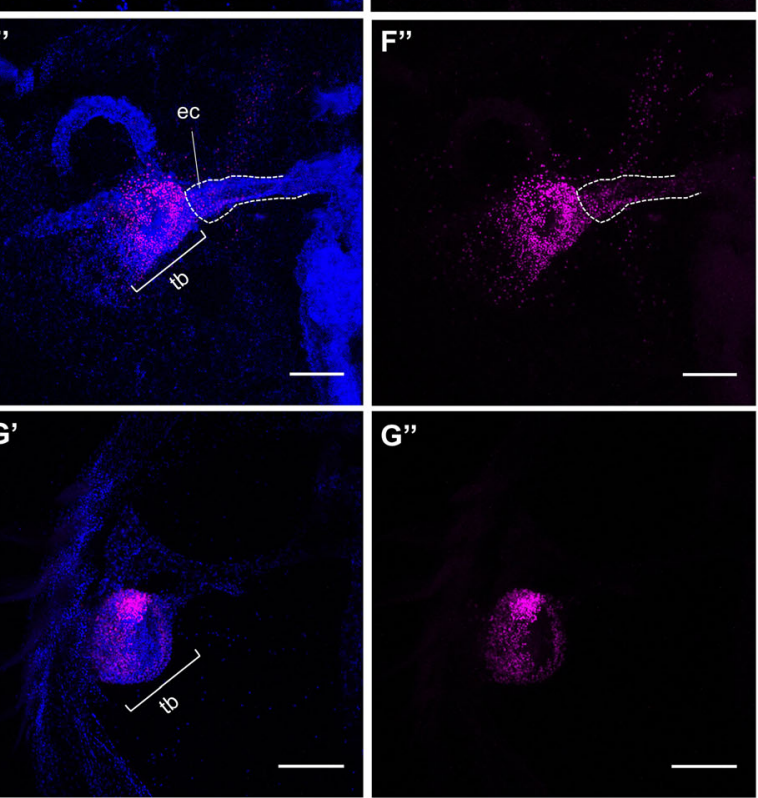

Fig. 9. (See legend on next page.) 
(See figure on previous page.)

Fig. 9. Regeneration occurs after removal of the main regions of active cell proliferation. A-C' DIC images of an uncut cydippid $(\mathbf{A})$ and cydippids after tentacle bulbs amputation $\left(\mathbf{B}-\mathbf{C}^{\prime}\right)$. Black dotted line rectangle in $\mathbf{C}$ shows the area corresponding to higher magnification on the right. D Schematic of the EdU incorporation experiment in cydippids in which both tentacle bulbs were amputated. E-G" Confocal stack projections of cydippids in which the tentacle bulbs were amputated oriented in a lateral view at different time points post amputation. The labeling corresponding to each panel is listed at the top of the columns, and the time following amputation is listed to the left of the rows. Dotted line rectangles in $\mathbf{E}, \mathbf{F}$, and $\mathbf{G}$ show the area corresponding to higher magnifications on the right. Dotted lines in $\mathbf{E}^{\prime}$ and $\mathbf{E}^{\prime \prime}$ and $\mathbf{F}^{\prime}$ and $\mathbf{F}^{\prime \prime}$ delimit the area corresponding to the endodermal canal. Nuclei of S-phase cells are labeled with EdU (magenta), and all nuclei are counterstained with DAPI (blue). Scale bars $=100 \mu \mathrm{m}$. Abbreviations: ts tentacle sheath, $\mathrm{t}$ tentacle, ec endodermal canal, tb tentacle bulb, hpa hours post amputation

25) - when cells at the wound site have already begun to cycle-fail to regenerate the missing structures (data not shown). Likewise, none of the apical organ amputated cydippids had regenerated any of the structures/cell types of the missing apical organ at $72 \mathrm{~h}$ following $\mathrm{HU}$ treatment, although the wound had correctly healed $\left(n=55\right.$, Fig. $\left.11 \mathrm{H}-\mathrm{J}^{\prime}\right)$. Although HU-treated animals failed to regenerate any of their missing structures, an aggregation of cells could be observed at the wound site (Fig. 11E, J'). These accumulations of quite large roundshaped cells could correspond to undifferentiated cells ready to re-form the missing structures but not able to proceed due to the blocking of cell proliferation. Importantly, the absence of EdU incorporation in dissected cydippids treated with $\mathrm{HU}$ confirmed that cell proliferation was completely suppressed (Additional file 12I-J'). From these observations we conclude that regeneration was impaired due to the absence of cell proliferation; therefore, cell proliferation is indispensable for normal ctenophore regeneration.

Regenerative ability is recovered after HU treatment ends Hydroxyurea has been shown to be reversible in cell culture following removal of the inhibitor [39] (Fig. 12A). HU treatments on cut cydippids showed that wound healing occurs normally without cell division. In order to determine whether regeneration could be initiated in HU-treated animals, we took surgically cut cydippids that had been exposed to $\mathrm{HU}$ over $48 \mathrm{~h}$, washed them in 1x FSW to remove the inhibitor, and then followed their development for $48 \mathrm{~h}$ to check for any ability to regenerate missing cell types (Fig. 12B, E). Surprisingly, 36 out of 94 bisected cydippids (38\%) had regenerated all the missing structures (comb rows, tentacle bulb, and tentacle) $48 \mathrm{~h}$ after $\mathrm{HU}$ had been removed (Fig. 12D-D”). Fifty-eight out of 94 bisected cydippids (62\%) showed some signs of regeneration but ultimately remained as "half animals," suggesting that these animals were not healthy enough to complete the regeneration process [40] (note that these animals were not fed during the treatment (2 days) or recovery period (2 additional days)). On the other hand, $100 \%$ of the cydippids, in which the apical organ was surgically removed and had been treated with $\mathrm{HU}$ for $48 \mathrm{~h}$, regenerated all the normal cell types of the apical organ ( $n=51$, Fig. $12 \mathrm{H}-$ I'). Altogether, these results show that ctenophore regeneration can be initiated over $48 \mathrm{~h}$ after wound healing is complete; hence, wound healing and regeneration appear to be two relatively independent events which can be temporally decoupled.

\section{Discussion}

In this study, we provide a detailed morphological and cellular characterization of wound healing and regeneration in the ctenophore Mnemiopsis leidyi. Wound closure is initiated immediately after injury, with the edges of the wound forming a round circumference that moves over the underlying mesoglea as it continues to reduce in diameter until they meet and forming a scar-less wound epithelium by $2 \mathrm{~h}$ following injury. Two main mechanisms seem to be pivotal for ctenophore wound closure: active cell migration of cells from the mesoglea underneath the epithelium upwards to the edges of the wound and dynamic extension of filopodia by the leading-edge epithelial cells in order to zipper the wound edges together. Cell migration and formation of actinbased cellular protrusions have been described during wound closure in multiple systems [41]; however, slight differences in those mechanisms have been observed in ctenophore wound healing. First, cell migration takes place in a "deep to surface" direction instead of a lateral direction, suggesting that only specific cell types from the mesoglea, such as mesenchymal cells, have the ability to migrate and contribute to gap closure. Second, wound-edge cells in ctenophores organize their cytoskeleton in spike-shaped filopodia rather than in plate-like extensions (lamellipodia), which happen to be the most common type of cellular protrusions among different model systems of wound healing, including the cnidarian Clytia [42]. Despite these minor differences, the fact that common mechanisms of wound closure are shared between early branching phyla like ctenophores and cnidarians and bilaterians (including vertebrates) proves the ancient origin of wound healing mechanisms as a strategy to maintain epithelium integrity. Wound healing in M. leidyi takes place through changes in cell behavior and occurs normally in the absence of cell proliferation. This observation is consistent with the majority of 


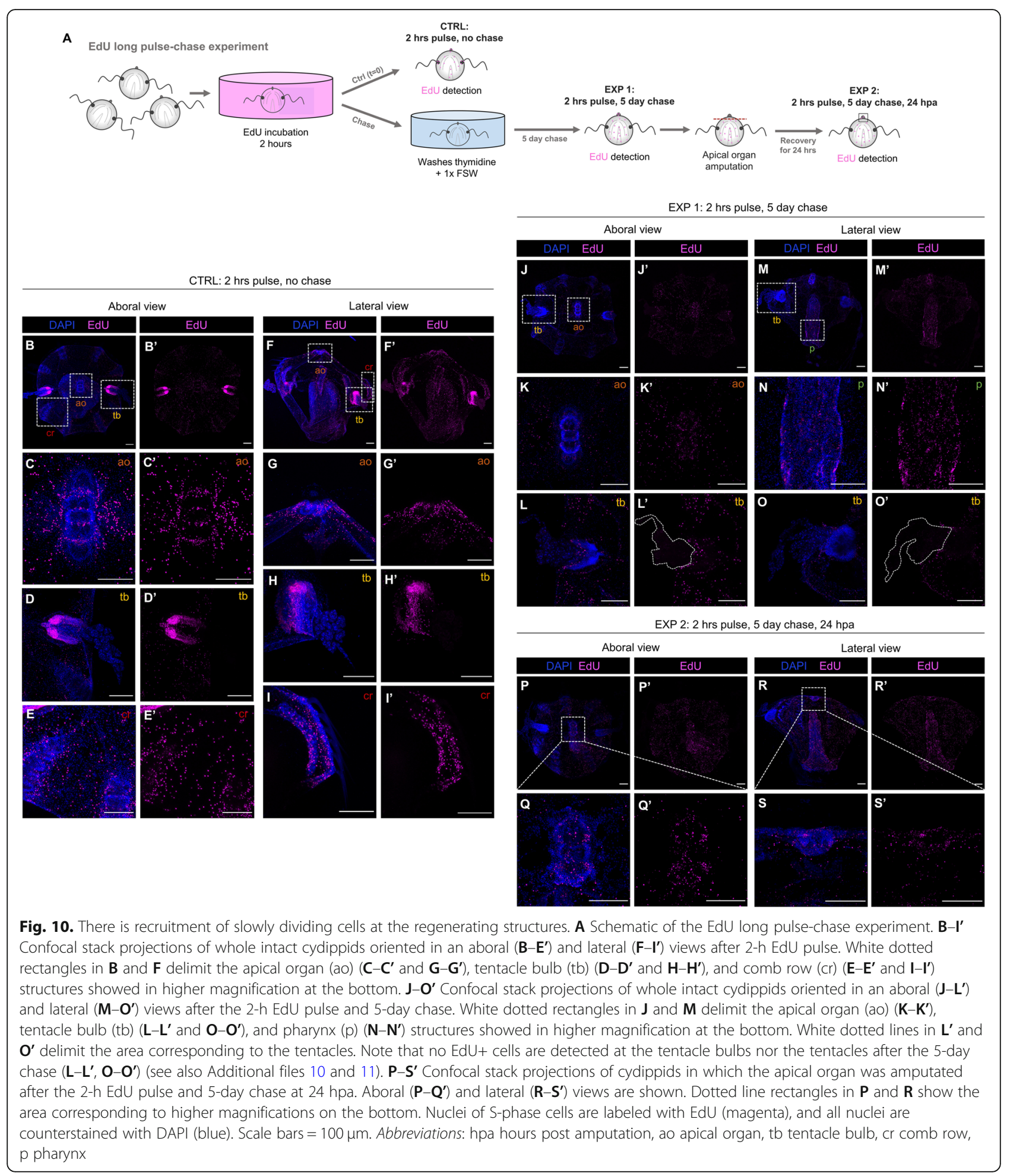

animal models of regeneration found in cnidarians [12, $20,42-44]$ as well as with the more phylogenetically distantly related marine annelid worm Platynereis dumerilii [37]. Following wound healing and prior to activation of cell proliferation in $M$. leidyi, there is remodeling of the tissue surrounding the wound and small numbers of round-shaped cells sparsely congregate at the wound site suggesting a reorganization of the tissue in order to prepare it for regeneration. Ctenophore regeneration, however, is strictly dependent on cell proliferation since none of the missing structures can be reformed in the absence of cell proliferation as proved by cell- 


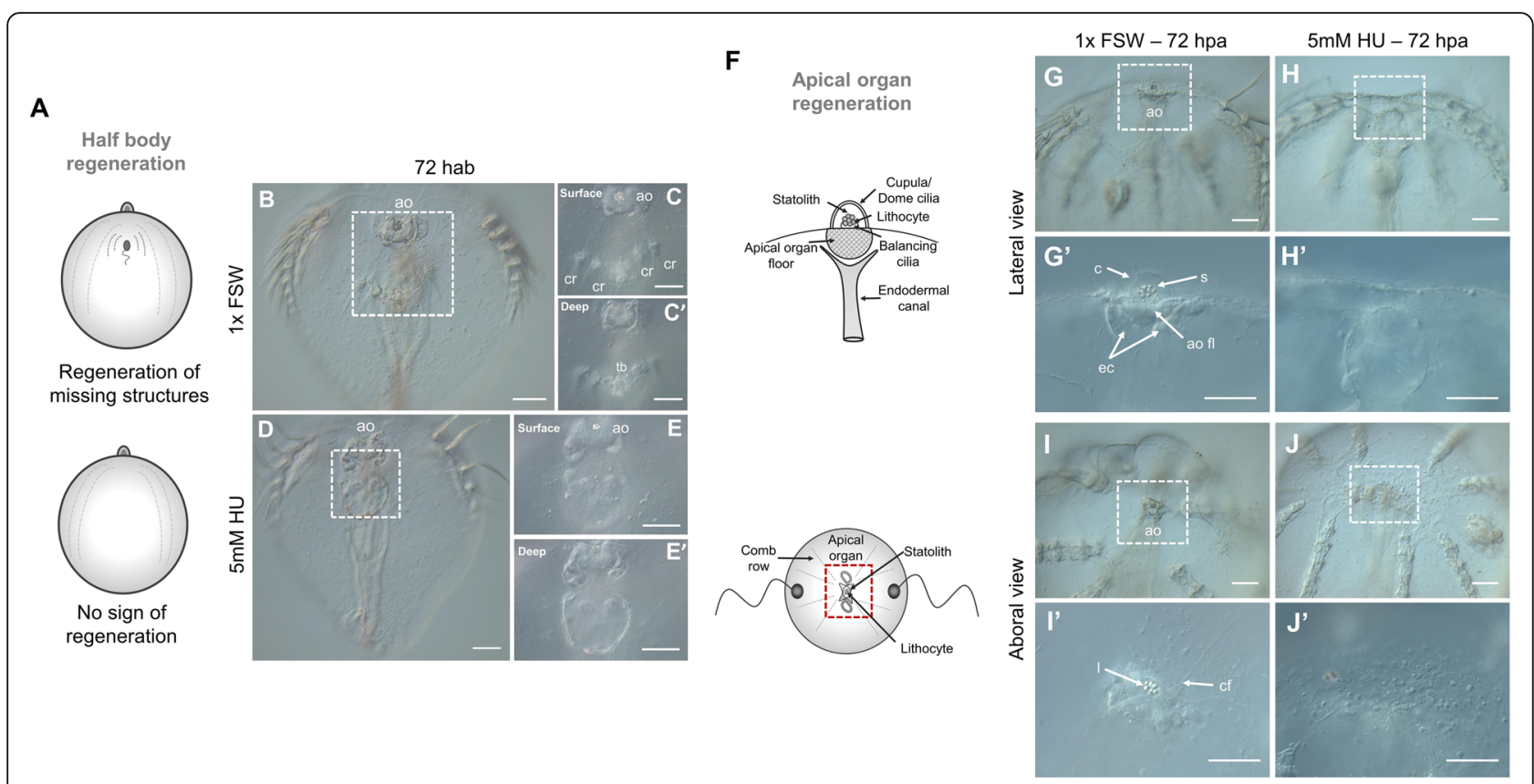

Fig. 11. Ctenophore regeneration does not occur in the absence of cell proliferation. A Schematic representation of the regeneration state of cydippids shown in the panels on the right. Cartoons correspond to lateral views of the cydippid's body bisected in half through the oral-aboral axis showing the cut site in the first plane. B-E' DIC images of bisected cydippids in a lateral view at 72 hab. The type of treatment corresponding to each panel is listed to the left of the rows. Dotted line rectangles in $\mathbf{B}$ and $\mathbf{D}$ show the area corresponding to higher magnifications on the right. Magnifications show surface (top) and deep (bottom) planes. Note that the wound site in treated cydippids is covered by a continuous epithelium but there is no sign of formation of missing structures. $\mathbf{F}$ Schematic representation of the apical sensory organ in lateral (top) and aboral (bottom) views. Red dotted rectangle at the bottom cartoon delimits the apical organ area shown in the images on the right. G-J' DIC images of cydippids in which the apical organ was amputated at 72 hpa orientated in lateral $\left(\mathbf{G}-\mathbf{H}^{\prime}\right)$ and aboral $\left(\mathbf{I}-\mathbf{J}^{\prime}\right)$ views. The type of treatment corresponding to each panel is listed to the top of the columns. Dotted line rectangles in $\mathbf{G}, \mathbf{H}, \mathbf{I}$, and $\mathbf{J}$ show the area corresponding to higher magnifications on the bottom. Note that treated cydippids show aggregation of cells around the surface of the wounded area although none of the missing apical organ structures are formed. Scale bars $=100 \mu \mathrm{m}$. Abbreviations: hab hours after bisection, hpa hours post amputation, ao apical organ, cr comb row, tb tentacle bulb, s statolith, c cupula, ao fl apical organ floor, ec endodermal canal, I lithocyte, cf ciliated furrow

proliferation blocking treatments. Indeed, a combination of both tissue remodeling and cell proliferation-based strategies has been previously described in the regeneration of other animals including annelids [17, 45], although in those cases tissue remodeling takes place simultaneously with cell proliferation-or even subsequent to activation of cell proliferation-and is involved in the regeneration of a specific structures such as parapodia [46] or the gut [47].

Cell proliferation in M. leidyi is first detected at the wound site between 6 and $12 \mathrm{~h}$ after surgery. The percentage of proliferating cells increases progressively during the first $12 \mathrm{~h}$ following injury and reaches a maximum around $24 \mathrm{~h}$ when the primordia of the missing structures are clearly delineated. Following this peak of cell proliferation, the percentage of cells undergoing cell division ( $\mathrm{S}$ phase) decreases while cells start to differentiate into their final structures. Comparing the kinetics of cell proliferation during regeneration of $M$. leidyi with the anthozoan cnidarian Nematostella vectensis [12], the percentage of dividing cells at the wound site is lower and the peak of maximum cell proliferation occurs earlier in ctenophore regeneration. In intact cydippids, cell proliferation is concentrated in two main areas of the cydippid's body corresponding to the tentacle bulbs. Some actively cycling cells are also found in the apical organ as well as few isolated dividing cells along the pharynx and under the comb rows. These results are consistent with previous EdU analysis performed in M. leidyi cydippids [27, 28] and adult ctenophores of the species Pleurobrachia pileus [36] where EdU labeling has been detected in the same spatially restricted populations identified as stem cell pools, specialized in the production of particular cell types. Pulse-chase experiments show concrete areas of active cell proliferation in the tentacle bulb and progressive migration of these proliferating cells from the tentacle bulb to the distal tips of the tentacle. These observations fit with histological and cellular descriptions of the tentacle apparatus $[36,48]$ which identified different populations of undifferentiated 


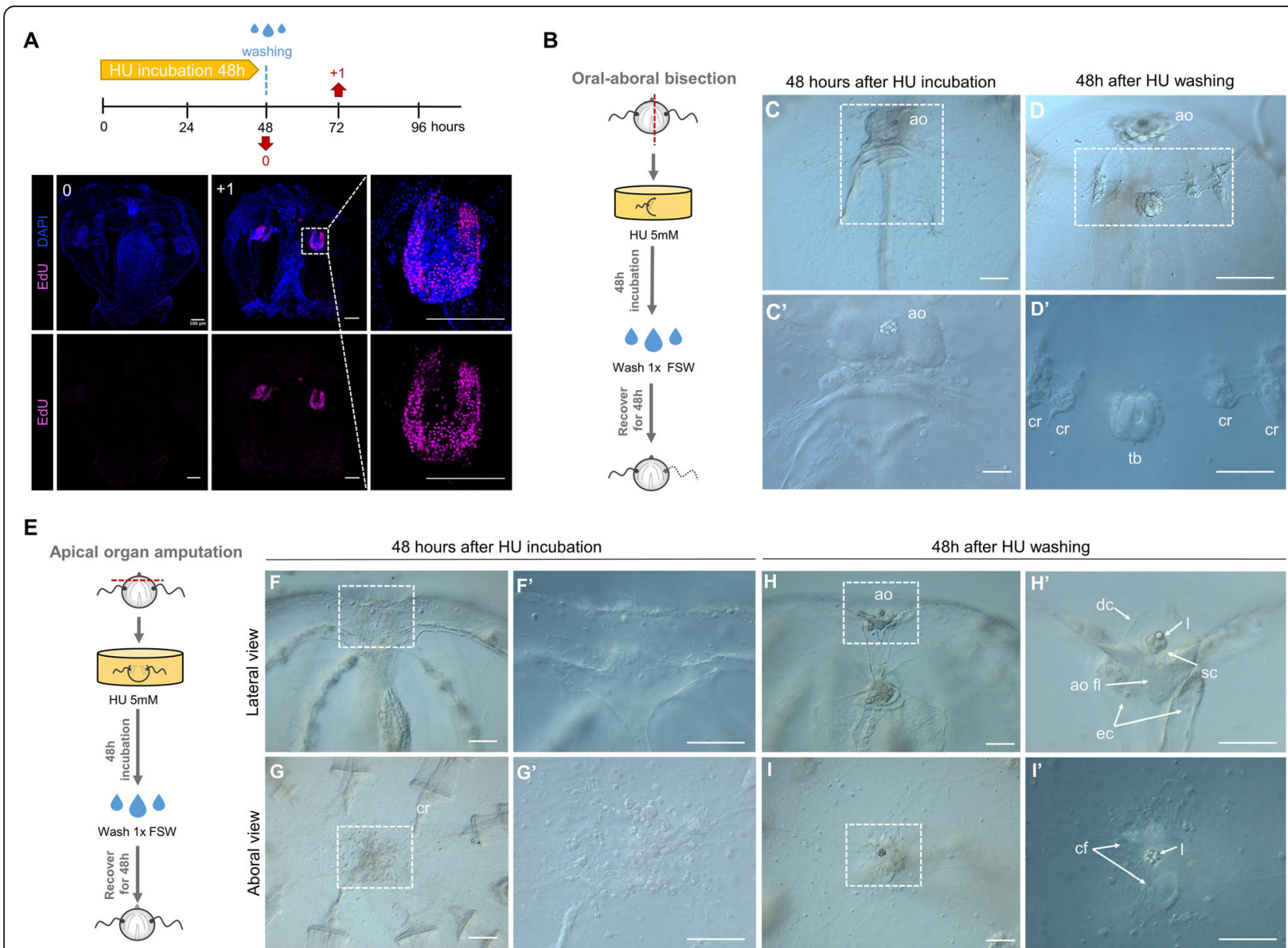

Fig. 12. Regenerative ability is recovered after $\mathrm{HU}$ treatment ends. A Reversible S-phase arrest after HU treatment as detected by EdU labeling performed at the indicated time points (red arrows). Nuclei of S-phase cells are labeled with EdU (magenta), and all nuclei are counterstained with DAPI (blue). Note that cells have already resumed cell cycle progression 1 day after HU wash. B, E Schematic representation of HU treatment and wash experiment in bisected cydippids through the oral-aboral axis (B) and cydippids in which the apical organ was amputated (E). C, $\mathbf{C}^{\prime}$ DIC images of bisected cydippids in lateral view showing the wound site at 48 hab. Note that there is no sign of regeneration of the missing structures. D, D' DIC images of bisected cydippids in lateral view showing the wound site at 96 hab. Note that all missing structures (comb rows and tentacle bulb) are regenerated. The dotted line rectangle in $\mathbf{C}$ and $\mathbf{D}$ shows the area corresponding to higher magnification at the bottom. F-G' DIC images of amputated cydippids oriented in a lateral (top panels) and aboral (bottom panels) view showing the wound site at $48 \mathrm{hpa}$. Note that there is no sign of regeneration of the missing structures. $\mathbf{H}-\mathbf{I}^{\prime}$ DIC images of amputated cydippids oriented in a lateral (top panels) and aboral (bottom panels) view showing the wound site at $96 \mathrm{hpa}$. Note that all components of the apical organ are regenerated. Dotted line rectangles in $\mathbf{F}, \mathbf{G}, \mathbf{H}$, and $\mathbf{I}$ show the area corresponding to higher magnification on the right. Scale bars $=100 \mu \mathrm{m}$. Abbreviations: hab hours after bisection, hpa hours post amputation, ao apical organ, cr comb row, tb tentacle bulb, dc dome cilia, I lithocyte, sc supporting cilia, ao fl apical organ floor, ec endodermal canal, cf ciliated furrows

progenitors source of all cell types found in the tentacle tissue. Surprisingly, long-term EdU retention is not detected in any of the cells of the tentacle apparatus suggesting that a population of "protected" slowly dividing stem cells might not exist in the tentacle bulb. This opens the question of the nature and origin of the progenitor cells responsible for the maintenance of the homeostasis of the tentacle structure. Perhaps tentacle bulb stem cells are continuously recruited from adjacent somatic cells rather than being derived from a uniquely committed set of slowly dividing "set aside" stem cells.
Interestingly, proliferating cells during regeneration do not organize to form a single large blastema-like structure from which a field of cells is reorganized to form the missing structures. Rather, small numbers of apparently undifferentiated cells assume the correct location of all missing structures simultaneously and differentiate in place. Considering the early branching phylogenetic position of ctenophores in the tree of life [49, 50], the absence of a blastema during ctenophore regeneration questions whether the formation of a blastema-which so far appears to have been reported in representatives 
of all phyla of regenerating animals [51]-is a conserved trait throughout the evolution of animal regeneration.

The strict requirement of cell proliferation and the absence of blastema formation could make ctenophore regeneration a case of non-blastemal cell proliferation-dependent regeneration. Although far less common than the blastemal-based regeneration, isolated cases of non-blastemal regeneration have been reported such as lens regeneration by transdifferentiation in newts [52] or liver regeneration by compensatory proliferation in humans [53]. EdU pulse-chase experiments after amputation show little to no contribution of cells originating in the main regions of active cell proliferation, including the tentacle bulbs, to the formation of missing structures. Moreover, the removal of these structures (tentacle bulbs), which have been reported to be localized areas of expression of genes involved in stem cell maintenance and regulation of cell fate [27, 28, 36]-and thus proposed to act as stem cell niches for regeneration-do not prevent regeneration. These observations argue against the contribution of discrete stem cell pools that migrate to and give rise to the reformation of lost structures, suggesting that new structures are generated from a local source of cells that become activated to give rise to missing structures/cell types. Longer pulse-chase experiments in which the animals where incubated in EdU for an extended period of time ( $2 \mathrm{~h}$ vs $15 \mathrm{~min})$ and then followed by a much longer chase allowed the identification of a population of slowly cycling (potentially stem) cells which could have escaped the initial short 15-min pulse. Three main observations can be taken from this experiment: (1) While the pattern of EdU+ proliferating cells after the long 2-h pulse coincides with the one observed after the short 15-min pulse, EdU+ cells after the chase are surprisingly no longer found in any of the cells forming the tentacle apparatus. This observation is consistent with the results obtained in the pulse-chase experiments after amputation and thus argues against the existence of a stem cell niche in the tentacle bulbs source of cells for the regenerative process. (2) Long retaining EdU+ cells (referred to as slowly dividing cells) are found uniformly distributed around the cydippid's body instead of being organized in discrete pools. This distribution pattern of cell proliferation could be comparable to the neoblast distribution pattern characteristic of planarians $[6,54,55]$, with the difference that neoblasts are known to reside in the planarian parenchyma-a mesenchymal tissue surrounding organ systems - [6], while these potential stem cells in ctenophores are found in both ectodermal and endodermal structures but apparently not in the mesenchymal cells of the mesoglea. (3) EdU+ long retaining cells are detected at regenerating structures after amputation indicating that these slow-cycling cells contribute to the reformation of new structures.

It is however important to note that our experiments do not give a definitive answer to the question of the origin of cells that give rise to new structures. There is the possibility that wound healing activates the dedifferentiation of cells at the wound site that are reprogrammed to give rise to whatever the appropriate set of cell types are needed to reconstitute the missing structures. The accumulation of large, round, apparently undifferentiated cells at the wound site during HU treatment is at least consistent with this scenario. On the other hand, wound healing could activate a dormant population of slowly dividing pluripotent stem cells located uniformly around the body that could migrate to the wound site and drive the regeneration process, which could have escaped the short pulse of EdU incorporation and re-entered the cell cycle as a consequence of injury. Although we saw some evidence of cells migrating from the underlying mesoglea to repair the wound site, we did not see any evidence of long range cell migration to the site of new cell type formation. Nonetheless, an early study leveraging the combination of cell lineage and specific cell deletion experiments in $M$. leidyi showed that comb plate regeneration cannot occur when the entire complement of cell lineage comb plate progenitors are killed during embryogenesis, suggesting that, at least for comb plate regeneration, a semicommitted somatic stem cell population is set aside during embryogenesis for comb plate replacement $[32,56]$. These data are premature and need to be extended to other cell types and later stages of the regenerative process; however, the stereotyped cell lineage seen in ctenophores provides exciting opportunities to pursue the origins of stem cells in the regenerative process in living animals.

Overall, our data, together with evidences from previous studies in ctenophores, are consistent with a model of ctenophore regeneration based on a combined contribution of active cell proliferation at the wound site together with the recruitment of slowly dividing cells to the regenerating structure (Fig. 13). The fact that no discrete pools of neoblast-type stem cells are identified in the ctenophore body, and the absolute requirement for cell proliferation, supports the hypothesis that proliferating cells at the wound site are the result of dedifferentiation events. On the other hand, whether these potential slowly dividing stem cells migrate to the wound site from close (local) or distant locations remains an open question. Gene expression data during the process of $M$. leidyi regeneration combined with cell tracing experiments will contribute to addressing these questions and 


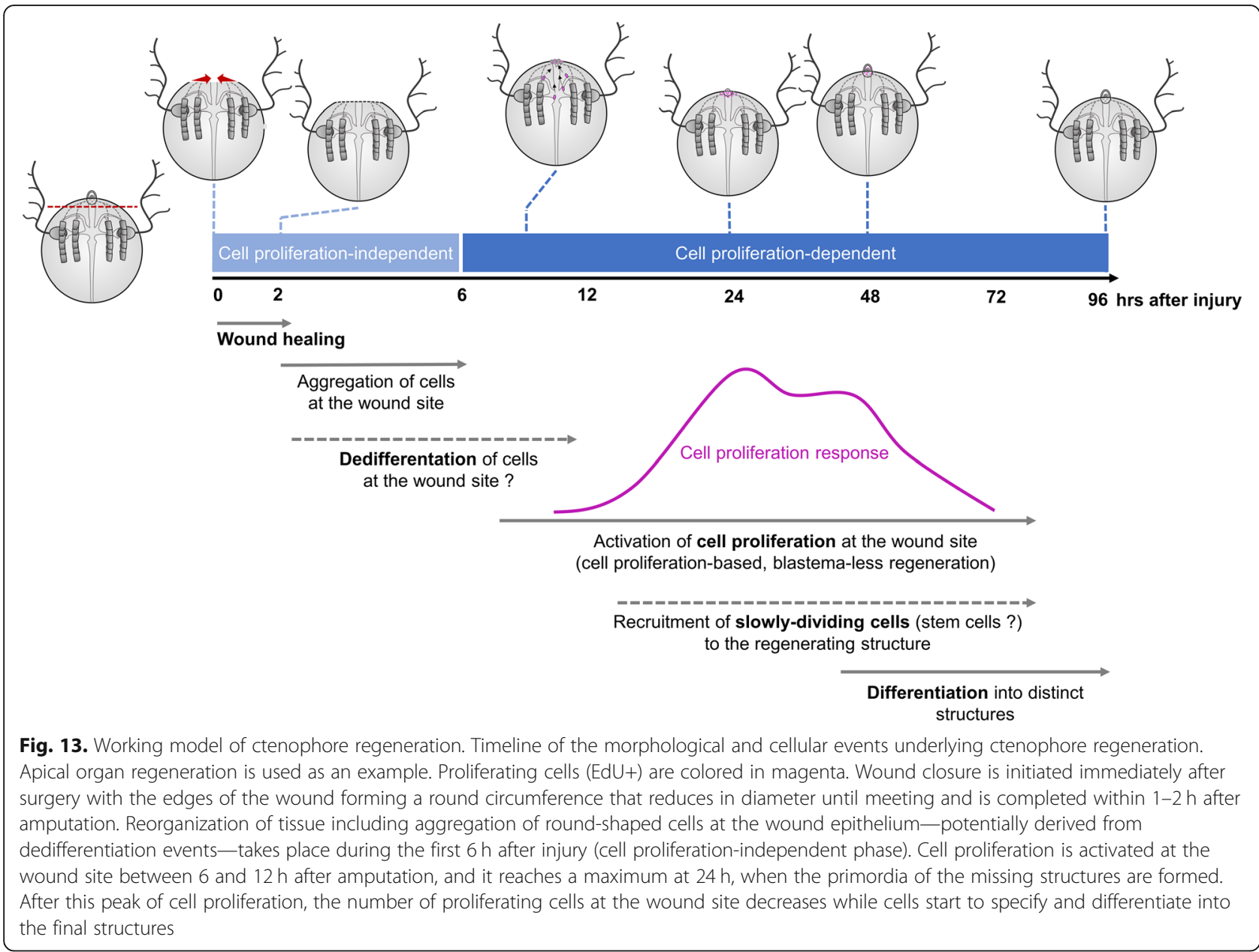

thus refine our working model of the origin of cells during ctenophore regeneration. Molecular data during regeneration will also be very valuable for performing comparisons of gene expression profiles between $M$. leidyi development [57] and regeneration and thus determine whether the molecular basis of ctenophore regeneration is similar to that deployed during development.

It is quite accepted that cells that re-epithelialize the wound (i.e., the "wound epithelium") provide the signals necessary to initiate regeneration $[58,59]$. In vertebrates, local thrombin activation is a signal for regeneration as shown by the study in which cultured newt myotubes returned to the cell cycle by the activity of a thrombingenerated ligand [60]. On the other hand, cellular interactions also seem to be important for the initiation of the regenerative response. One such case is the dorsoventral interaction between the wounded tissues during wound healing in planarians which has been shown to play a key role in the formation of the blastema and, hence, initiation of regeneration [61]. These observations suggest that wound healing and regeneration are two closely related processes which need to take place sequentially in time. Our results, however, show that ctenophore regeneration can be initiated over $48 \mathrm{~h}$ after wound healing is completed, suggesting that regeneration can be initiated without direct signaling induced by the wounded epithelium. Regeneration of the missing structures is not initiated until the cell-proliferation blocking treatment is removed. Hence, another case scenario is that the wound epithelium produces persistent signaling necessary for triggering regeneration at the time of wound healing, but the process cannot be initiated due to the blocking of cell proliferation. This is consistent with the proposed hypothesis for Nematostella that the key transition from wound healing to a state of regeneration is the activation of cell proliferation [62]. Studying and comparing the molecular signaling involved in both ctenophore wound healing and regeneration will be very useful to get further insight into the relationship between these two processes.

\section{Conclusions}

In conclusion, this study provides a thorough description of the morphological and cellular events during 
ctenophore wound healing and regeneration and compares them with the regenerative strategies followed by other metazoans. The early branching phylogenetic position of ctenophores together with their rapid, highly stereotyped development and remarkable ability to regenerate makes them a key system to gain a better understanding of the evolution of animal regeneration.

\section{Methods}

\section{Animal care}

Regeneration experiments were performed on juvenile Mnemiopsis leidyi cydippid stages due to their small size and ease of visualization and because their power of regeneration is the same as adults [30]. M. leidyi cydippids were obtained from spawning adults collected from either the floating docks located around Flagler Beach area, FL, USA, or from the floating docks at the east end of the Bridge of Lions on Anastasia Island, St. Augustine, FL, USA. For spawning, freshly collected adults were kept in constant light for at least two consecutive nights and then individual animals transferred into 6" diameter glass culture dishes filled with 1x FSW and placed in total darkness. After approximately $3-4 \mathrm{~h}$ in the dark at $22-24{ }^{\circ} \mathrm{C}$, these self-fertile hermaphroditic animals had spawned and embryos were collected by pipetting them into a new dish of UV treated $1.0 \mu \mathrm{m}$ filtered full strength seawater $(1 \mathrm{x} F \mathrm{FW})$ using a transfer pipette. Embryos were raised at $22-24{ }^{\circ} \mathrm{C}$ for approximately $5-7$ days and fed once a day with rotifers (Brachionus plicatilis, $160 \mu \mathrm{m}$ ) (Reed Mariculture, Campbell, CA, USA).

\section{Animal surgeries}

Operations were done in $35-\mathrm{mm}$ plastic petri dishes with 2-mm thick silicon-coated bottoms (SYLGARD-184, Dow Corning, Inc.) on cydippids $1.5-3.0 \mathrm{~mm}$ in diameter. Cydippids were transferred in to the operation dishes in $0.2 \mu \mathrm{m}$ filtered seawater and cut using hand pulled glass needles from Pyrex capillaries [30]. Three types of operations were performed: (1) Oral-aboral bisections, in which animals were cut longitudinally through the esophageal plane generating two "half animals." The operations were performed such that one half retained an intact apical organ while the remaining half lacked the apical organ. Only the halves retaining the apical organ were studied here as these halves regenerate to normal animals in a high percentage of the cases [30]. (2) Apical organ amputations, involving the removal of the apical organ by cutting perpendicular to the oralaboral axis above the level of the tentacle bulbs. (3) Tentacle bulb amputations, consisting in the removal of both tentacle bulbs (Fig. 1d). Following surgery, halves containing the apical organ, amputated cydippids without the apical organ, and amputated cydippids without tentacle bulbs were returned to $35-\mathrm{mm}$ plastic Petri dishes filled with $0.2 \mu \mathrm{m}$ filtered 1x FSW for the desired length of time without feeding. All the regenerating experiments were performed at $22-24{ }^{\circ} \mathrm{C}$.

To study the wound healing process, juvenile cydippids were punctured generating a round-shaped wound of approximately $200-400 \mu \mathrm{m}$ of diameter. Animals were placed in a small drop of water on a siliconized (Rain-X, Inc.) treated microscope slide, and punctures were performed by pinching the epithelium layer using a pair of sharp needles (World Precision Instruments, Sarasota, FL. USA, Cat\#500341). After puncture, animals were checked for the presence of an epithelial gap with the edges of the wound forming a small circumference exposing the mesoglea, and then they were immediately mounted for live imaging (see below).

\section{Tissue labeling and cell counts}

\section{Detection of cell proliferation by incorporation of EdU}

To label proliferating cells, cydippids were fixed and processed for fluorescent detection of incorporated EdU using the Click-iT EdU labeling kit (Invitrogen Thermo Fisher Scientific, Waltham, MA, USA, Cat \#C10424), which incorporates EdU in cells that are undergoing the $\mathrm{S}$ phase of the cell cycle. Specifically, intact cydippids between 1.5 and $3.0 \mathrm{~mm}$ in diameter or bisected/amputated cydippids were incubated in EdU labeling solution $(100 \mu \mathrm{M}$ of EdU in $1 \mathrm{x}$ FSW $)$ for $15 \mathrm{~min}$. For pulse-chase experiments, cydippids were incubated with $100 \mu \mathrm{M}$ EdU in $1 \mathrm{x}$ FSW for $15 \mathrm{~min}$, washed three times with $100 \mu \mathrm{M}$ thymidine in $1 \mathrm{x}$ FSW, and maintained in increasing volumes of $1 \mathrm{x}$ FSW until fixation. Control or operated cydippids were embedded in $1.2 \%$ low melt agarose $\left(25^{\circ} \mathrm{C}\right.$ melting temperature, USB, Inc. Cat \#32830) in a $35-\mathrm{mm}$ plastic petri dish (Fisher, Inc. Cat $\# 08757100 \mathrm{~A})$ and fixed in ice-cold $100 \mathrm{mM}$ HEPES $\mathrm{pH}$ 6.9; $0.05 \mathrm{M}$ EGTA; $5 \mathrm{mM} \mathrm{MgSO} 4 ; 200 \mathrm{mM} \mathrm{NaCl}$; $1 \mathrm{x}$ PBS; $3.7 \%$ formaldehyde; $0.2 \%$ glutaraldehyde; $0.2 \%$ Triton X-100; and $1 \mathrm{x}$ FSW $(0.2 \mu \mathrm{m}$ filtered $)$ for $1 \mathrm{~h}$ at room temperature with gentle rocking [63] (Additional file 5). Animals were then washed several times in PBS-0.02\% Triton X-100, then one time in PBS- $0.2 \%$ Triton X-100 for $20 \mathrm{~min}$, and again several times in PBS-0.02\% Triton $\mathrm{X}-100$. The EdU detection reaction was performed according to the manufacturer instructions using the Alexa-567 reaction kit. Following detection, cydippids were washed three times in PBS- $0.02 \%$ Triton X-100, and subsequently, all nuclei were counterstained with DAPI (Invitrogen, Carlsbad, CA. USA, Cat. \#D1306) at $1.43 \mu \mathrm{M}$ in $1 \times$ PBS for $2 \mathrm{~h}$. Cydippids were mounted in TDE mounting media (97\% TDE, $970 \mu \mathrm{l}$ 2,2'-thiodiethanol (Sigma-Aldrich, St. Louis, MO, USA); $30 \mu \mathrm{l}$ PBS) for visualization. To quantify the percentage of EdU-labeled cells at the wound site, Zeiss 710 confocal z-stack projections of operated cydippids were generated using Fiji 
software (Image J) and individual cells were digitally counted using Imaris, Inc. software (Bitplane, Switzerland). Only the area and z-stacks surrounding the wound site were used for the analysis. EdU+ cells and nuclei were counted separately in 5 to 10 specimens for each time point. The number of EdU-positive nuclei was divided by the total number of nuclei stained with DAPI generating a ratio corresponding to the percentage of EdU+ cells.

\section{Immunofluorescence}

Proliferating cells in $\mathrm{M}$ phase were detected using an antibody against phospho-histone 3 ( $\mathrm{PH} 3$ - phospho S10). Control or operated cydippids were fixed as mentioned above. Fixed cydippids were washed several times in PBS-0.02\% Triton X-100 (PBT 0.02\%), then one time in PBS-0.2\% Triton X-100 (PBT 0.2\%) for $10 \mathrm{~min}$, and again several times in $\mathrm{PBT} 0.02 \%$. They were then blocked in 5\% normal goat serum (NGS; diluted in PBT $0.2 \%$ ) for $1 \mathrm{~h}$ at room temperature with gentle rocking. After blocking, specimens were incubated in antiphospho-histone H3 antibody (ARG51679, Arigo Biolaboratories, Taiwan) diluted 1:150 in 5\% NGS overnight at $4{ }^{\circ} \mathrm{C}$. The day after, specimens were washed at least five times with PBS-0.2\% Triton X-100. Secondary antibody (Alexa Fluor 488 goat anti-rabbit IgG (A-11008, Invitrogen, Carlsbad, CA, USA) was diluted 1:250 in 5\% NGS and incubated overnight at $4{ }^{\circ} \mathrm{C}$ with gentle rocking. After incubation, specimens were washed three times with PBT $0.02 \%$ and incubated with DAPI $(0.1 \mu \mathrm{g} /$ $\mu l$ in $1 \times$ PBS; Invitrogen, Carlsbad, CA, USA, Cat. \#D1306) for $2 \mathrm{~h}$ to allow nuclear visualization. Samples were then rinsed in $1 \times \mathrm{PBS}$ and mounted in TDE mounting media (97\%TDE, $970 \mu \mathrm{l}$ 2,2'-thiodiethanol (Sigma-Aldrich, St. Louis, MO, USA); $30 \mu \mathrm{l}$ PBS) for visualization.

\section{Cell proliferation inhibitor treatment with hydroxyurea (HU)}

Cell proliferation was blocked using the ribonucleotide reductase inhibitor hydroxyurea (HU) (Sigma-Aldrich, St. Louis, MO. USA). Incubations with hydroxyurea were performed at a concentration of $5 \mathrm{mM}$ in $1 \mathrm{x}$ FSW. Operated cydippids were exposed to continuous incubations of $5 \mathrm{mM} \mathrm{HU}$ for $48-72 \mathrm{~h}$. HU solution was exchanged with freshly diluted inhibitor every $12 \mathrm{~h}$. For washing experiments, the effect of $\mathrm{HU}$ was reversed by removal and replacement of the drug with $1 \mathrm{x}$ FSW.

\section{Imaging}

\section{Visualization of living animals}

In order to immobilize live animals for scoring and time-lapse observations, we utilized a custom made optically transparent jammed microgel. A solution of azobisisobutyronitrile (Sigma Aldrich, Inc.) and $\mathrm{N}^{\prime}$-Methylene
Bisacrylamide (Sigma Aldrich, Inc.) in ethanol is prepared at a 99:1 AAM to MBA molar ratio [64, 65]. The solution is sparged with nitrogen for $30 \mathrm{~min}$, then placed into a preheated $60^{\circ} \mathrm{C}$ oil bath. After approximately 30 min, the solution becomes hazy and a white precipitate begins to form. The reaction mixture is heated for an additional $4 \mathrm{~h}$, the precipitate collected by vacuum filtration and rinsed with ethanol on the filter. The microparticles are triturated with $500 \mathrm{~mL}$ of ethanol overnight. The solids are again collected by vacuum filtration and dried on the filter for $\sim 10 \mathrm{~min}$. The particles are dried completely in a $50^{\circ} \mathrm{C}$ vacuum oven to yield a loose white powder. The purified microgel powder is dispersed in $0.2 \mu \mathrm{m}$ filtered seawater at a concentration of $7.5 \%(\mathrm{w} /$ $\mathrm{w})$ and mixed at $3500 \mathrm{rpm}$ in a centrifugal speed mixer $[64,66]$ in 5-min intervals until no aggregates are apparent. The microgel is then left to swell overnight, yielding mounting medium made from packed hydrogel microparticles. The $7.5 \%$ microgel was placed around the operated/punctured cydippids mounted in a hydrophobic-treated slide (Rain-Ex, Inc.). For short live imaging, a cover slip with clay corners was placed over the specimens; for long time-lapse live imaging, the corners of the cover slip were sealed using Vaseline in order to maintain the humidity of the preparation.

\section{Microscopes and image analysis}

In vivo differential interference contrast (DIC) images were captured using a Zeiss Axio Imager M2 coupled with an AxioCam (HRc) digital camera. Fluorescent confocal imaging was performed using a Zeiss LSM 710 confocal microscope (Zeiss, Gottingen, Germany) using either a $\times 10 / 0.3$ NA dry objective, a $\times 20 / 0.8$ NA dry objective, or a $\times 40 / 1.3 \mathrm{NA}$ water immersion objective. For time-lapse imaging, DIC images were captured using a Zeiss Axio Imager M2 coupled with a Rolera EM-C2 camera (Surrey, BC. Canada). Stacks were taken every minute. Generation of Z-stack projections, time-lapse movies, and image processing was performed using Fiji software [67].

\section{Additional files}

\footnotetext{
Additional file 1: Movie S1. Wound healing time-lapse. DIC microscopy time-lapse movie of wound closure after puncture of the wound pictured in Fig. 2. Note the migration of mesogleal cells to the edges of the wound during the wound closure process. Scale bar $=100 \mu \mathrm{m}$. (AVI $13286 \mathrm{~kb})$

Additional file 2: Figure S5. EdU pulse and chase experiment in the tentacle bulb. (A-D') Confocal stack projections of tentacle bulbs and tentacles in lateral view. The time of the chase is listed to the left of the rows, and the labeling corresponding to each panel is listed at the top of the columns. Nuclei of S-phase cells are labeled with EdU (magenta) combined with a differential interference contrast image of the tissue (DIC). Scale bars $=50 \mu \mathrm{m}$. (TIFF $7376 \mathrm{~kb}$ )
} 
Additional file 3: Figure S6 and S7. EdU staining at 96 hab and 72 hpa. $\left(A-A^{\prime \prime}\right)$ Confocal stack projections of a bisected cydippid through the oral-aboral axis at 96 hab oriented in a lateral view showing the cut site in the first plane. White asterisks point to tentacle bulbs of the uncut site. (B-C') Confocal stack projections of cydippids in which the apical organ was amputated at $72 \mathrm{hpa}$. Examples of the two types of EdU pattern observed at this time-point are shown. Nuclei of S-phase cells are labeled with EdU (magenta) and all nuclei are counterstained with DAPI (blue). The pattern of EdU labeling corresponding to each time-point is shown in a cartoon on the left of the rows. Scale bars $=100 \mu \mathrm{m}$. Abbreviations: hours after bisection (hab), hours post amputation (hpa), polar field (pf). (TIFF 5018 kb)

Additional file 4: Figure S6 and S7. PH3 immunostaining after oralaboral bisection and apical organ amputation. (A-B") Confocal stack projections of a bisected cydippid through the oral-aboral axis oriented in a lateral view showing the cut site in the first plane. The time following surgery is listed to the left of the rows. M-phase cells are stained with anti$\mathrm{PH} 3$ (green) and all nuclei are counterstained with DAPI (blue). (C-D') Confocal stack projections of regenerating apical organs in a lateral view. The time following surgery is listed to the left of the rows. M-phase cells are stained with anti-PH3 (green) combined with DIC image of the tissue. DIC images of surface and deep planes are shown for $24 \mathrm{hpa}$. Scale bars $=100 \mu \mathrm{m}$. Abbreviations: hours after bisection (hab), hours post amputation (hpa). (TIFF $2990 \mathrm{~kb}$ )

Additional file 5: Figure S8. Controls of the EdU pulse-chase experiments in regenerating cydippids. (A) Diagram of the experimental setup. (B-D') Confocal stack projections of an uncut cydippid just after EdU incubation (control 1). (E-F') Confocal stack projections of an amputated cydippid just after the cut (control 2). Nuclei of S-phase cells are labeled with EdU (magenta) and all nuclei are counterstained with DAPI (blue). White dotted rectangles in (B) and (E) show the area corresponding to higher magnifications on the right. White arrows in $\left(E^{\prime}\right)$ point to the wound site. Note that no EdU+ cells are detected at the wound site just after the cut while EdU staining is found in the normal areas of cell proliferation (tentacle bulbs). Scale bars $=100 \mu \mathrm{m}$. (TIFF $3490 \mathrm{~kb}$ )

Additional file 6: Movie S10. Z-stack of whole body intact cydippid oriented in an aboral view after a 2-h EdU incubation pulse. Nuclei of Sphase cells are labeled with EdU (magenta) combined with a differential interference contrast image of the tissue (DIC). Note that EdU+ cells are located at the surface epidermis but not at the mesenchymal cells of the deep mesoglea. Scale bar $=100 \mu \mathrm{m}$. (AVI $35542 \mathrm{~kb}$ )

Additional file 7: Movie S10. Z-stack of whole body intact cydippid oriented in a lateral view after a 2-h EdU incubation pulse. Nuclei of S-phase cells are labeled with EdU (magenta) combined with a differential interference contrast image of the tissue (DIC). Scale bar =100 $\mu \mathrm{m}$. (AVI $37973 \mathrm{~kb}$ )

Additional file 8: Movie S10. Z-stack of the apical organ area of a cydippid oriented in an aboral view after a 2 -h incubation pulse. Nuclei of S-phase cells are labeled with EdU (magenta) combined with a differential interference contrast image of the tissue (DIC). Note that most of the EdU+ cells are found at the epidermis surrounding the apical organ area and some EdU+ cells are located at the apical organ floor. Scale bar $=100 \mu \mathrm{m}$. (AVI $12509 \mathrm{~kb}$ )

Additional file 9: Movie S10. Z-stack of the comb row area of a cydippid after a 2-h incubation pulse. Nuclei of S-phase cells are labeled with EdU (magenta) and all nuclei are counterstained with DAPI (blue), combined with a differential interference contrast image of the tissue (DIC). Note that $\mathrm{EdU}+$ cells are found at the endodermal canals that connect the comb rows with the digestive system. Scale bar $=100 \mu \mathrm{m}$. (AVI $17268 \mathrm{~kb}$ )

Additional file 10: Movie S10. Z-stack of the tentacle apparatus of a cydippid oriented in an aboral view exposed to a 2-h EdU pulse followed by a 5-day chase. Nuclei of S-phase cells are labeled with EdU (magenta) combined with a differential interference contrast image of the tissue (DIC). Note that no EdU+ cells are found at the tentacle bulb nor the tentacle. Scale bar $=100 \mu \mathrm{m}$. (AVI $5305 \mathrm{~kb}$ )

Additional file 11: Movie S10. Z-stack of the tentacle apparatus of a cydippid oriented in a lateral view exposed to a 2-h EdU pulse followed by a 5-day chase. Nuclei of S-phase cells are labeled with EdU (magenta) combined with a differential interference contrast image of the tissue
(DIC). Note that no EdU+ cells are found at the tentacle bulb nor the tentacle. Scale bar $=100 \mu \mathrm{m}$. (AVI $1456 \mathrm{~kb})$

Additional file 12: Figure S11. $5 \mathrm{mM}$ Hydroxyurea (HU) blocks cell proliferation in intact and bisected cydippids. (A) Schematic of cell proliferation inhibitor experiments with $\mathrm{HU}$ in intact cydippids. Confocal stack projections of intact cydippids oriented in an aboral view at $24 \mathrm{~h}$ (B$\mathrm{C}^{\prime}$ ) and $72 \mathrm{~h}\left(\mathrm{D}-\mathrm{E}^{\prime}\right)$ after $\mathrm{HU}$ incubation. The type of treatment is listed at the top of the columns, and the labeling corresponding to each panel is listed to the left of the rows. Nuclei of S-phase cells are labeled with EdU (magenta) and all nuclei are counterstained with DAPI (blue). Note that no EdU+ nuclei were detected in treated cydippids after $\mathrm{HU}$ incubation. (F) Schematic of cell proliferation inhibitor experiments with $\mathrm{HU}$ in dissected cydippids. $\left(\mathrm{G}-\mathrm{H}^{\prime}\right)$ Confocal stack projections of an untreated bisected cydippid oriented in a lateral view at 72 hab. (I-I') Confocal stack projections of a bisected cydippids treated with $\mathrm{HU}$ at $72 \mathrm{hab}$. (J-J') Confocal stack projections of cydippids amputated from the apical organ treated with $\mathrm{HU}$ at $72 \mathrm{hpa}$. The type of treatment and the time following bisection are listed at the top of the columns, and the labeling corresponding to each panel is listed to the left of the rows. The dotted line rectangle in $(G)$ shows the area corresponding to higher magnifications on the right. The white asterisks in $(G),\left(G^{\prime}\right)$ and $(I)$ point to the tentacle bulb of the uncut site. The white rectangle in $(J)$ indicates the area of apical organ regeneration. Nuclei of S-phase cells are labeled with EdU (magenta) and all nuclei are counterstained with DAPI (blue). Note that no EdU+ nuclei were detected and none of the missing structures had regenerated in treated cydippids. Scale bars $=100 \mu \mathrm{m}$. Abbreviations: hours after bisection (hab), hours post amputation (hpa). (TIFF $4240 \mathrm{~kb}$ )

\section{Abbreviations}

1x FSW: 1x filtered sea water; hab: Hours after bisection; hpa: Hours post amputation; EdU: 5-Ethynyl-20-deoxyuridine; PH3: Phospho-histone 3; HU: Hydroxyurea; DIC: Differential interference contrast

\section{Acknowledgements}

We thank the owners and staff of Marker 8 Hotel and Marina in St. Augustine for allowing us access to their floating docks for animal collection, and all the members of our lab for assistance and discussions.

\section{Authors' contributions}

JRM contributed to the conceptualization, investigation, writing of the original draft, review, and editing; TE and TEA contributed to the design and synthesis of microgels; MQM, contributed to the conceptualization, supervision, writing of the original draft, review, and editing. All authors read and approved the final manuscript.

\section{Funding}

This work was supported by the National Science Foundation (NSF) grant IOS-1755364. The funders had no role in the study design, data collection and interpretation, or the decision to submit the work for publication.

\section{Availability of data and materials}

All data generated or analyzed during this study are included in this published article and its supplementary information files.

\section{Ethics approval and consent to participate}

Not applicable.

\section{Competing interests}

The authors declare that they have no competing interests.

\section{Author details}

${ }^{1}$ The Whitney Laboratory for Marine Bioscience, 9505 N, Ocean Shore Blvd, St. Augustine, FL 32080-8610, USA. ²Department of Materials Science and Engineering, Herbert Wertheim College of Engineering, University of Florida, Gainesville, Florida 32611, USA. ${ }^{3}$ Department of Mechanical and Aerospace Engineering, Herbert Wertheim College of Engineering, University of Florida, Gainesville, Florida 32611, USA. 
Received: 15 May 2019 Accepted: 30 August 2019

Published online: 11 October 2019

\section{References}

1. Bely $A E$, Nyberg KG. Evolution of animal regeneration: re-emergence of a field. Trends Ecol Evol. 2010;25(3):161-70. https://doi.org/10.1016/j.tree.2009. 08.005.

2. Alvarado AS, Tsonis PA. Bridging the regeneration gap: genetic insights from diverse animal models. Nat Rev Genet. 2006;7(11):873-84. https://doi. org/10.1038/nrg1923.

3. Tanaka EM, Reddien PW. The cellular basis for animal regeneration. Dev Cell. 2011;21(1):172-85. https://doi.org/10.1016/j.devcel.2011.06.016.

4. Bryant SV, Endo T, Gardiner DM. Vertebrate limb regeneration and the origin of limb stem cells. Int J Dev Biol. 2002;46:887-96.

5. McCusker C, Bryant SV, Gardiner DM. The axolotl limb blastema: cellular and molecular mechanisms driving blastema formation and limb regeneration in tetrapods. Regeneration. 2015;2(2):54-71. https://doi.org/10.1002/reg2.32.

6. Reddien PW, Alvarado AS. Fundamentals of planarian regeneration. Annu Rev Cell Dev Biol. 2004;20(1):725-57 http://www.annualreviews.org/doi/10. 1146/annurev.cellbio.20.010403.095114.

7. Park HD, Ortmeyer AB, Blankenbaker DP. Cell division during regeneration in hydra. Nature. 1970;228:227-31

8. Cummings SG, Bode HR. Head regeneration and polarity reversal in Hydra attenuata can occur in the absence of DNA synthesis. Wilhelm Roux's Arch Dev Biol. 1984;194(2):79-86.

9. Dübel S, Schaller HC. Terminal differentiation of ectodermal epithelial stem cells of hydra can occur in G2 without requiring mitosis or S phase. J Cell Biol. 1990;110(April):939-45

10. Holstein TW, Hobmayer E, David CN. Pattern of epithelial cell cycling in hydra. Dev Biol. 1991;148(2):602-11.

11. Chera S, Ghila L, Dobretz K, Wenger Y, Bauer C, Buzgariu W, et al. Apoptotic cells provide an unexpected source of Wnt3 signaling to drive hydra head regeneration. Dev Cell. 2009;17(2):279-89. https://doi.org/10.1016/j.devcel. 2009.07.014.

12. Passamaneck YJ, Martindale MQ. Cell proliferation is necessary for the regeneration of oral structures in the anthozoan cnidarian Nematostella vectensis. BMC Dev Biol. 2012;12. https://doi.org/10.1186/1471-213X-12-34.

13. Baguna J, Salo E, Auladell C. Regeneration and pattern formation in planarians. III. That neoblasts are regeneration and pattern formation in planarians. III. That neoblasts are totipotent stem cells and the cells totipotent stem cells and the cells. Development. 1989:107:77-86.

14. Newmark PA, Sánchez AA. Bromodeoxyuridine specifically labels the regenerative stem cells of planarians. Dev Biol. 2000;220(2):142-53 http://dx. doi.org/53.10.1006/dbio.2000.9645.

15. Wagner DE, Wang IE, Reddien PW. Clonogenic neoblasts are pluripotent adult stem cells that underlie planarian regeneration. Science. 2011; 332(6031):811-6. https://doi.org/10.1126/science.1203983.

16. Bely AE. Early events in annelid regeneration: a cellular perspective. Integr Comp Biol. 2014;54(4):688-99. https://doi.org/10.1093/icb/icu109.

17. Özpolat BD, Bely AE. Developmental and molecular biology of annelid regeneration: a comparative review of recent studies. Curr Opin Genet Dev. 2016:40:144-53. https://doi.org/10.1016/j.gde.2016.07.010.

18. Zattara EE, Turlington KW, Bely AE. Long-term time-lapse live imaging reveals extensive cell migration during annelid regeneration. BMC Dev Biol. 2016;16(1):1-21. https://doi.org/10.1186/s12861-016-0104-2.

19. de Jong DM, Seaver EC. Investigation into the cellular origins of posterior regeneration in the annelid Capitella teleta. Regeneration. 2017:1-17 http:// doi.wiley.com/10.1002/reg2.94.

20. Bradshaw B, Thompson K, Frank U. Distinct mechanisms underlie oral vs aboral regeneration in the cnidarian Hydractinia echinata. Elife. 2015;2015(4): 1-19. https://doi.org/10.7554/eLife.05506.

21. Kragl M, Knapp D, Nacu E, Khattak S, Maden M, Epperlein HH, et al. Cells keep a memory of their tissue origin during axolotl limb regeneration. Nature. 2009;460(7251):60-5. https://doi.org/10.1038/nature08152.

22. Pang K, Martindale MQ. Comb jellies (Ctenophora): a model for basal metazoan evolution and development. Cold Spring Harb Protoc. 2008;3(11): 1-11. https://doi.org/10.1101/pdb.emo106.

23. Henry $\mathrm{JQ}$, Martindale $\mathrm{MQ}$. Regulation and regeneration in the ctenophore Mnemiopsis leidyi. Dev Biol. 2000;227(2):720-33. https://doi.org/10.1006/ dbio.2000.9903.
24. Martindale $\mathrm{MQ}$. The onset of regenerative properties in ctenophores. Curr Opin Genet Dev. 2016;40:113-9. https://doi.org/10.1016/j.gde.2016. 06.017 .

25. Jager M, Manuel M. Ctenophores: an evolutionary-developmental perspective. Curr Opin Genet Dev. 2016;39:85-92. https://doi.org/10.1016/j. gde.2016.05.020

26. Fischer AHL, Pang K, Henry JQ, Martindale MQ. A cleavage clock regulates features of lineage-specific differentiation in the development of a basal branching metazoan, the ctenophore Mnemiopsis leidyi. Evodevo. 2014;5(1). https://doi.org/10.1186/2041-9139-5-4.

27. Schnitzler CE, Simmons DK, Pang K, Martindale MQ, Baxevanis AD. Expression of multiple Sox genes through embryonic development in the ctenophore Mnemiopsis leidyi is spatially restricted to zones of cell proliferation. Evodevo. 2014;5(1):1-17. https://doi.org/10.1186/ 2041-9139-5-15.

28. Reitzel AM, Pang K, Martindale MQ. Developmental expression of "germline"- and "sex determination"-related genes in the ctenophore Mnemiopsis leidyi. Evodevo. 2016;7(1):1-16. https://doi.org/10.1186/ s13227-016-0051-9.

29. Freeman G. Studies on regeneration in the creeping ctenophore, Vallicula multiformis. 123, J Morphol. 1967. p. 71-783 doi: https://doi. org/10.1002/jmor.1051230107

30. Martindale MQ. The ontogeny and maintenance of adult symmetry properties in the ctenophore, Mnemiopsis mccradyi. Dev Biol. 1986;118:55676. https://doi.org/10.1016/0012-1606(86)90026-6.

31. Coonfield BR. Regeneration in Mnemiopsis leidyl Agassiz. Biol Bull. 1936; 71:421-8

32. Martindale $\mathrm{MQ}$, Henry JQ. Development and regeneration of comb plates in the ctenophore Mnemiopsis leidyi. Biol Bull. 1996;191(2):290-2. https://doi. org/10.1086/BBLv191n2p290.

33. Tamm SL. Regeneration of ciliary comb plates in the ctenophore Mnemiopsis leidyi. I Morphology J Morphol. 2012;273:109-20. https://doi. org/10.1002/jmor.11016

34. Salic A, Mitchison TJ. A chemical method for fast and sensitive detection of DNA synthesis in vivo. PNAS. 2008;105(7). https://doi.org/10.1073/pnas. 0712168105.

35. Chehrehasa F, Meedeniya ACB, Dwyer P, Abrahamsen G, Mackay-Sim A. EdU, a new thymidine analogue for labelling proliferating cells in the nervous system. J Neurosci Methods. 2009;177(1):122-30. https://doi.org/10. 1016/j.jneumeth.2008.10.006

36. Alié $A$, Leclère $L$, Jager $M$, Dayraud C, Chang $P$, Le Guyader $H$, et al. Somatic stem cells express Piwi and vasa genes in an adult ctenophore: ancient association of "germline genes" with stemness. Dev Biol. 2011;350(1):183-97. https://doi.org/10.1016/j.ydbio.2010.10.019.

37. Planques A, Malem J, Parapar J, Vervoort M, Gazave E. Morphological, cellular and molecular characterization of posterior regeneration in the marine annelid Platynereis dumerilii. Dev Biol. 2019;445(2):189-210. https:// doi.org/10.1016/j.ydbio.2018.11.004.

38. Young CW, Hodaas S. Hydroxyurea: inhibitory effect on DNA metabolism. Science $1964: 146: 1172-4$.

39. Adams RLP, Lindsay J. Hydroxyurea. Reversal of inhibition and use as a cellsynchronizing agent. J Biol Chem. 1967;242(6):1314-7.

40. Bading KT, Kaehlert S, Chi X, Jaspers C, Martindale MQ, Javidpour J. Food availability drives plastic self-repair response in a basal metazoan-case study on the ctenophore Mnemiopsis leidyi A. Agassiz Sci Rep. 2017:7(1):1-9. https://doi.org/10.1038/s41598-017-16346-w.

41. Begnaud S, Chen T, Delacour D, Mège RM, Ladoux B. Mechanics of epithelial tissues during gap closure. Curr Opin Cell Biol. 2016;42:52-62. https://doi.org/10.1016/j.ceb.2016.04.006.

42. Kamran Z, Zellner K, Kyriazes H, Kraus CM, Reynier JB, Malamy JE. In vivo imaging of epithelial wound healing in the cnidarian Clytia hemisphaerica demonstrates early evolution of purse string and cell crawling closure mechanisms. BMC Dev Biol. 2017;17(1):1-14. https://doi.org/10.1186/s12861017-0160-2.

43. Singer II. Tentacular and oral-disc regeneration in the sea anemone, Aiptasia diaphana. J Embryol Exp Morphol. 1971;26(2):253-70. https://doi.org/10. 1007/BF00597293.

44. Amiel AR, Johnston HT, Nedoncelle K, Warner JF, Ferreira S, Röttinger E. Characterization of morphological and cellular events underlying oral regeneration in the sea anemone, Nematostella vectensis. Int J Mol Sci. 2015: 16(12):28449-71. https://doi.org/10.3390/ijms161226100. 
45. De Jong DM, Seaver EC. A stable thoracic Hox code and epimorphosis characterize posterior regeneration in Capitella teleta. PLoS One. 2016;11(2). https://doi.org/10.1371/journal.pone.0149724.

46. Berrill NJ. Regeneration in Sabella pavonina (Sav.) and other sabellid worms. J Exp Zool. 1931;58:495-523.

47. Zattara EE, Bely AE. Evolution of a novel developmental trajectory: fission is distinct from regeneration in the annelid Pristina leidyi. Evol Dev. 2011;13(1): 80-95. https://doi.org/10.1111/j.1525-142X.2010.00458.X.

48. Borisenko I, Ereskovsky AV. Tentacular apparatus ultrastructure in the larva of Bolinopsis infundibulum (Lobata: Ctenophora). Acta Zool. 2013;94(2):193-202. https:/doi.org/10.1111/j.1463-6395.2011.00542.x.

49. Dunn CW, Hejnol A, Matus DQ, Pang K, Browne WE, Smith SA, et al. Broad phylogenomic sampling improves resolution of the animal tree of life. Nature. 2008;452(7188):745-9. https://doi.org/10.1038/nature06614.

50. Ryan JF, Pang K, Schnitzler CE, Nguyen AD, Moreland RT, Simmons DK, et al. The genome of the ctenophore Mnemiopsis leidyi and its implications for cell type evolution. Science. 2008:452(7188):745-9. https://doi.org/10.1038/ nature06614.

51. Sánchez AA. Regeneration in the metazoans: why does it happen? BioEssays. 2000;22(6):578-90.

52. Tsonis PA, Del Rio-Tsonis K. Lens and retina regeneration: transdifferentiation, stem cells and clinical applications. Exp Eye Res. 2004;78(2):161-72. https://doi. org/10.1016/j.exer.2003.10.022

53. Michalopoulos GK, DeFrances M. Liver regeneration. Science. 1997; 276(5309):60-6. https://doi.org/10.1007/b99968.

54. Forsthoefel DJ, Newmark PA. Emerging patterns in planarian regeneration. Curr Opin Genet Dev. 2009;19(4):412-20. https://doi.org/10.1016/j.gde.2009. 05.003.Emerging.

55. Baguñà J. The planarian neoblast: the rambling history of its origin and some current black boxes. Int J Dev Biol. 2012;56(1-3):19-37. https://doi.org/ 10.1387/ijdb.113463jb.

56. Martindale MQ, Henry JQ. Intracellular fate mapping in a basal metazoan, the ctenophore Mnemiopsis leidyi, reveals the origins of mesoderm and the existence of indeterminate cell lineages. Dev Biol. 1999;214:243-57. https:// doi.org/10.1006/dbio.1999.9427.

57. Levin M, Anavy L, Cole AG, Winter E, Mostov N, Khair S, et al. The middevelopmental transition and the evolution of animal body plans. Nature. 2016:531:637. do: https://doi.org/10.1038/nature16994.

58. Brockes JP, Kumar A. Comparative aspects of animal regeneration. Annu Rev Cell Dev Biol. 2008;24(1):525-49 http://www.annualreviews.org/doi/10.1146/ annurev.cellbio.24.110707.175336.

59. Owlarn S, Klenner F, Schmidt D, Rabert F, Tomasso A, Reuter H, et al. Generic wound signals initiate regeneration in missing-tissue contexts. Nat Commun. 2017:8(1):1-13. https://doi.org/10.1038/s41467-017-02338-x.

60. Tanaka EM, Drechsel DN, Brockes JP. Thrombin regulates S-phase re-entry by cultured newt myotubes. Curr Biol. 1999;9(15):792-9. https://doi.org/10. 1016/S0960-9822(99)80362-5.

61. Kato K, Orii H, Watanabe K, Agata K. The role of dorsoventral interaction in the onset of planarian regeneration. Development. 1999;126(5):1031-40. https://doi.org/10.1242/dev.031682

62. DuBuc TQ, Traylor-Knowles N, Martindale MQ. Initiating a regenerative response; cellular and molecular features of wound healing in the cnidarian Nematostella vectensis. BMC Biol. 2014;12(1):1-20. https://doi.org/10.1186/ 1741-7007-12-24.

63. Salinas-Saavedra M, Martindale MQ. Improved protocol for spawning and immunostaining embryos and juvenile stages of the ctenophore Mnemiopsis leidyi. Protocol Exch. 2018. https:/doi.org/10.1038/protex.2018.092.

64. Bhattacharjee T, Zehnder SM, Rowe KG, Jain S, Nixon RM, Sawyer WG, et al. Writing in the granular gel medium. Sci Adv. 2015:1(8). https://doi.org/10. 1126/sciadv.1500655

65. O'Bryan CS, Kabb CP, Sumerlin BS, Angelini TE. Jammed polyelectrolyte microgels for 3D cell culture applications: rheological behavior with added salts. ACS Appl Bio Mater. 2019;2(4):1509-17. https://doi.org/10.1021/ acsabm.8b00784.

66. Bhattacharjee T, Gil CJ, Marshall SL, Urueña JM, O'Bryan CS, Carstens M, et al. Liquid-like solids support cells in 3D. ACS Biomater Sci Eng. 2016;2(10):1787-95. https://doi.org/10.1021/acsbiomaterials.6b00218.

67. Schindelin J, Arganda-Carreras I, Frise E, Kaynig V, Longair M, Pietzsch T, et al. Fiji: an open-source platform for biological-image analysis. Nat Methods. 2012:9(7):676-82. https://doi.org/10.1038/nmeth.2019.

\section{Publisher's Note}

Springer Nature remains neutral with regard to jurisdictional claims in published maps and institutional affiliations.
Ready to submit your research? Choose BMC and benefit from:

- fast, convenient online submission

- thorough peer review by experienced researchers in your field

- rapid publication on acceptance

- support for research data, including large and complex data types

- gold Open Access which fosters wider collaboration and increased citations

- maximum visibility for your research: over $100 \mathrm{M}$ website views per year

At BMC, research is always in progress.

Learn more biomedcentral.com/submissions 